\title{
درجة ممارسة رؤساء الأقسام في جامعة نجران للرقابة الإداريـة من وجهة نظر أعضاء هيئة التدريس
}

\author{
د. هادي سالم العجمي

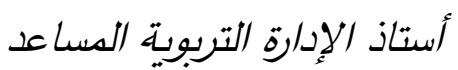 \\ كلية العلوم وآلاداب بشرورة، جامعة نجران
}

مستخلص. هدفت هذه الدراسة إلى التعرف على درجة ممارسة رؤساء الأقسام في جامعة نجران للرقابة الإدارية من

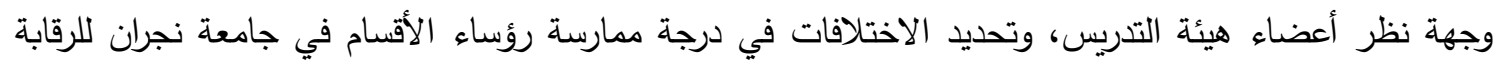

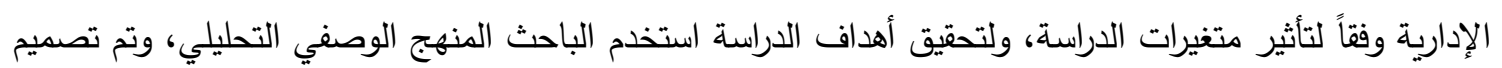

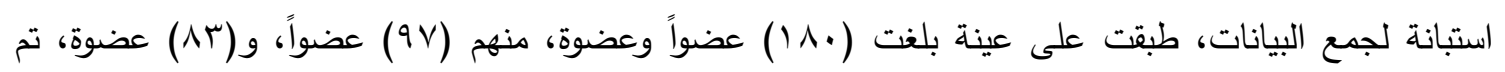

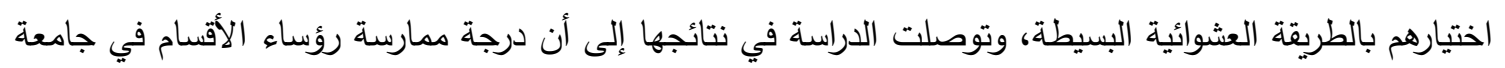

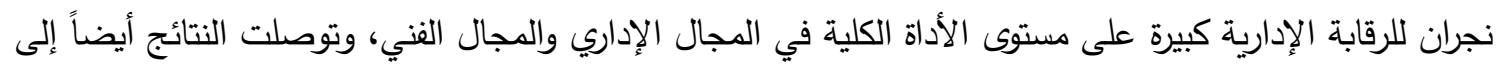

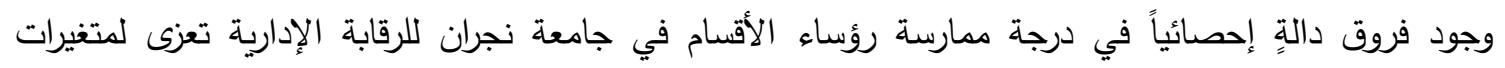

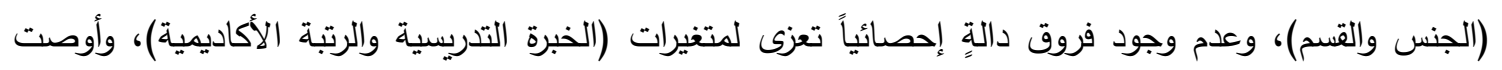

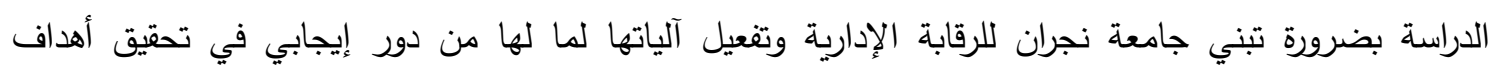
الجامعة ورؤيتها، وتطوير أداء العاملين فيها.

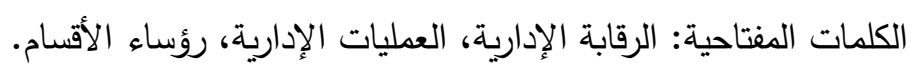

مسؤولية إعداد وتطوير المنظمات للتعامل مع مختلف التطورات والمشكلات التي تواجهها بشكل دائم، والإفادة من التغيير بأكبر قدر ممكن، وتوجيهه لصالح الأفراد والجماعات. وتتبع أهمية الإدارة في العصر الحاضر من الحاءل الحاجة

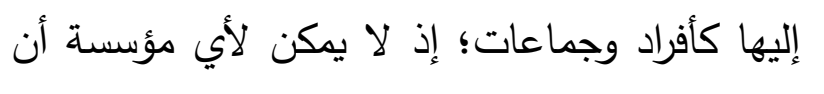

\section{المقدمة والخلفية النظرية}

شهد العالم مع نهاية القرن العشرين تغيرات سريعة ومتلاحقة في جميع المجالات الاقتصادية والسياسية

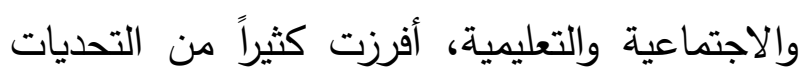

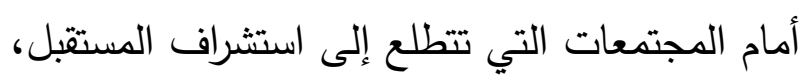
وفرضت على الإدارة في القرن الحادي والعشرين التى التشرين 
والوظائف المختلفة لكل وحدة إدارية إذ يتطلب توزيع الأعمال رقابة على الأفراد للقيام بمهامهم وواجباتهم

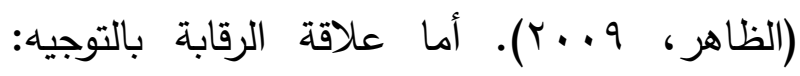
فترتبط بكافة عناصره من قيادة وتحفيز واتصال؛ فالقيادة تضع بصمتها على عملية الرقابة للتأكد من أنها فعالة، والتحفيز يؤثر في دافعية المسؤولين عن الرقابة للعمل الجاد المتقن، والاتصال الجيد بين العاملين والمسؤولين يسهل عمل الرقابة دن حيث اكتشاف الأخطاء ومعالجتها (الدرة والصباغ، (Y. (Y). وترتبط الرقابة بتقييم الأداء ارتباطاً وثيقاً؛

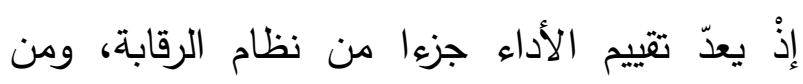
الأمور التي تعنى بها من خلال تحليل جوانب القوة والضعف لأداء العاملين لتحديد كفاءتهم وقدرتهم على أداء المهام والأنشطة المختلفة، وتهدف الرقابة إلى تقييم الأداء، وتشجيع الجيد منه، وعلاج الأداء

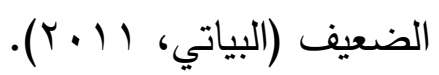
وأكدت العديد من الدراسات كدراسة (الكوفحي

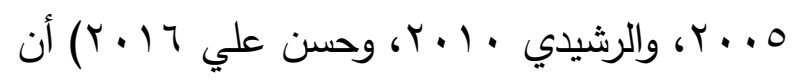
الرقابة الإدارية تسهم بشكل كبير في تطوير أداء العاملين، مما يعزز الروح المعنوية لديهم وانتمائهم للمؤسسة، وترفع من مستوى أدائهم، وتسهم أيضاً في حل المشكلات التي تواجهها المنظمة ككل. ويعتبر رئيس القسم أحد أهم القيادات الجامعية، فهو قائد إداري من جهة وقائد تعليمي من جهة أخرى؛ فهو مسؤول عن تسيير أمور القسم وضبطها، وتنفيذ تعليمات الإدارة العليا بالكلية، كما يقوم بدور فعال
تتطور بدون وجود إدارة فاعلة، باعتبارها مطلباً رئيسياً لقيامها، واستثمار ما لديها من موارد مالية وبشرية ومادية، فنجاح المؤسسات في تحقيق أهدافها ورسالتها يرتبط بالكيفية التي يدير بها القائد هذه المنظمة، وبالنمط القيادي الذي يمارسه، وبالصفات والمهارات التي يمتلكها، والتي يجب أن يوظفها في إيجاد بيئة تساعد في زيادة الإنتاجية، وتسهم في تحقيق الأهداف المنشودة للمنظمة (شقير ، Y I ب). وتمثل الرقابة إحدى الوظائف الإدارية الرئيسية،

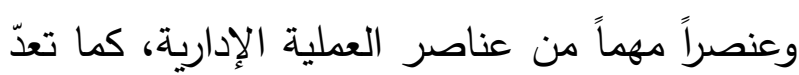
الحلقة الأخيرة من حلقات العمليات الإدارية، وهي تتكامل مع الحلقات الأخرى ولا تنفصل عنها، وإنما هي جزء لا يتجزأ منها وبدونها يصعب تحقيق الفعالية الإدارية، وتحقيق الإدارة لأهدافها والقيام بوظيفتها على أكمل وجه، فهي ليست مقصورة على الإدارة العليا، وإنما تمتد للمستويات الإدارية المتوسطة والدنيا (طراونة وعبد الهادي، (1) • (Y). وترتبط الرقابة الإدارية بالعمليات الإدارية الأخرى كالتخطيط والتنفيذ والتوجيه والتتييم، ففي علاقة الرقابة مع التخطيط: لا يمكن القيام بمهام الرقابة الإدارية إلا بوجود خطة واضحة وأهداف محددة، فالتخطيط يمد الرقابة بمعايير الأداء، والرقابة تمدّ التخطيط بحجم الإنجاز وإمكانية التعديل والتطوير مستقبلا (الشواشرة، ه . . †). وفي علاقة الرقابة مع التظيم: فيتم تقسيم المؤسسة إلى وحدات إدارية متخصصة، ووضع وصف فني وعملي للمهام 
وتحليلها وتوجيها نحو المسار الصحيح (عياصرة، .$(r \cdot . \wedge$

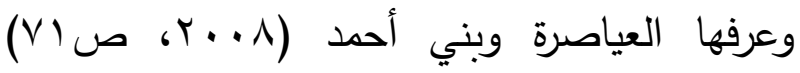
بأنها: "متابعة الأعمال أولا بأول لتقويم الأخطاء

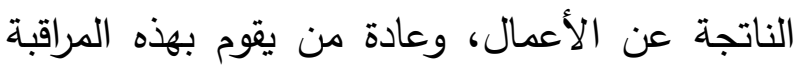
وحدات تكون داخل تنظيم الرقابة السابقة واللاحقة

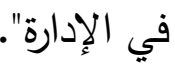

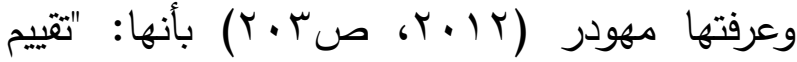
وتصحيح العمليات داخل المنظمة ضمن إطار من المستويات القياسية الداخلية والخارجية، وتستأصل الرقابة الناجحة الفوضى، وتوفر الثبات داخل المنظمة حتى يتم تحقيق الأهداف".

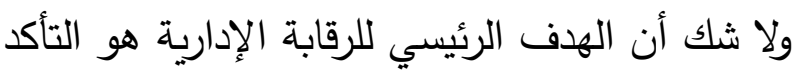

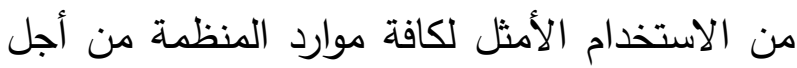
تحقيق أهدافها، وتبرز الحاجة إلى العملية الرقابية في التالي: حدوث أخطاء في عمليات التخطيط بدءاً من عمليات تحديد الأهداف وترجمتها إلى معايير قابلة للقياس، وحدوث أخطاء أثناء التنفيذ من خلال وجود اختلاف في النتائج الفعلية عن المخطط لها، وحدوث تغيرات في الظروف الخارجية المختلفة مما يتطلب قدراً كبيراً من المرونة لمواجهة الظروف لفروف

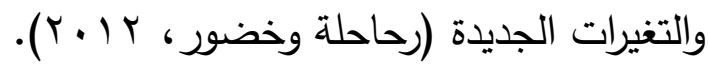

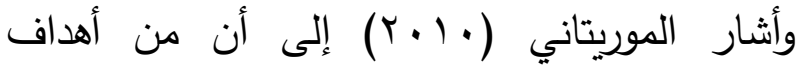
الرقابة الإدارية: التعرف على المشكلات التي تواجه المنظمات، واكتشاف الأخطاء وتقديم الحلول لها من خلال وضع نظام رقابي سليم يضمن منع تكرار
في تطوير الأقسام والإشراف على جميع شؤون القسم

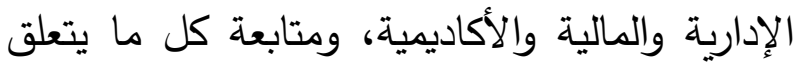
بشؤون أعضاء هيئة التدريس، بالإضافة إلى مهامه الأكاديمية والبحثية، وهو بذلك قائد للقسم في مختلف المسؤوليات والمهام الإدارية والمالية (محسن 11 +.r، برقعان r ( • ب). وقد شهدت المؤسسات التربوية توسعاً ملحوظاً في جميع أركانها، فكبر حجمها، وتعددت اختصاصاتها

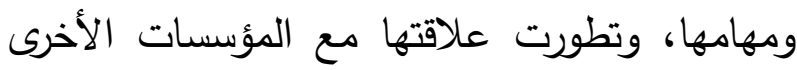
في المجتمع، ومن هنا برزت أهمية الرقابة الإدارية لمعالجة الأخطاء والانحرافات في العمل لمساعدة هذه المؤسسات على تحقيق أهدافها ورؤيتها ورسالتها وفق ما خطط له (بني عبد الله، A| • r، ص (I).

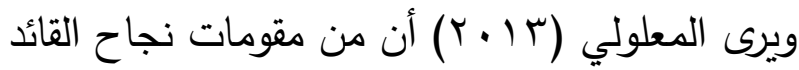
في المؤسسات التعليمية قدرته على متابعة سير العمل، وتقع عليه مسؤولية رقابية على العاملين بغرض تقويم أعمالهم، فتطور المؤسسات التعليمية يعتمد على مدى تطبيق العملية الرقابية وممارستها

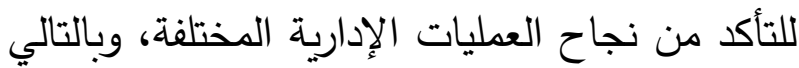
يعود ذلك بالنفع عليها ويرفع من مستواها، أما ضعف العملية الرقابية فيعدّ من أهم أسباب فثل دئل النظام التعليمي في المؤسسات التعليمية. وقد تعددت مفاهيم الرقابة الإدارية، فتتاول الباحثون المفهوم من زوايا متعددة، واتفقوا جميعهم في أنها عملية قياس النتائج الفعلية ومقارنتها مع ما هو مخطط له، ومن ثم تشخيص أسباب الانحرافات 
عندهم، كما تمثل قدوة حسنة لهم في تتمية جانب الرقابة الذاتية. وقد أُجريت دراسات عدة في مجال الرقابة الإدارية في مختلف المؤسسات التربوية، يمكن استعراضها في ما يلي: أجرى جريجورسكو (Grigorescu, 2003) دراسة هدفت إلى الكثف عن الرقابة الإدارية وتأثيرها على

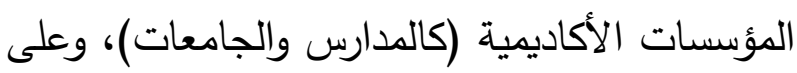
تعزيز الروح التعاونية بين المعلمين في مدينة

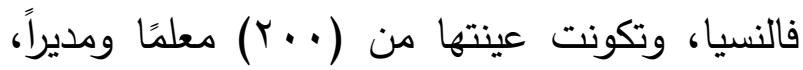
مستخدمةً المنهج الوصفي التحليلي، وبينت نتونت نتائج

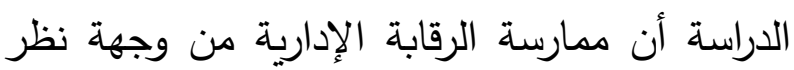
المعلمين ضرورة في سيادة الرقابة الداخلية والذاتية لديهج، كما بيّتت النتائج أيضاً أن مفهوم الرقابة الدية الإدارية أصبح أكثر وضوحًا بعد تطبيق برامج لائر تدريبية تشجع الرقابة والمساءلة في المدارس وتزيد الوعي لديهج بهذا المفهوم. وقام ميزلا (Mizala, 2004) بدراسة هدفت إلى لى لوائل التعرف على دور الرقابة الإدارية وأثرها في أداء المعلمين وإنتاجيتهم في المدارس الحكومية في أمريكا، وتكونت عينتها من ( • ع) معلماً ومديراً، وقد

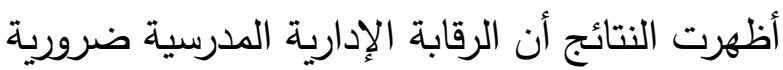
للتأكد من سير العمل، وتحقيق الأهداف المرسومة

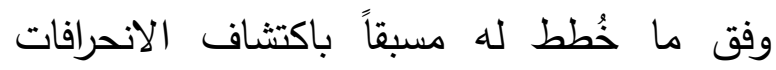

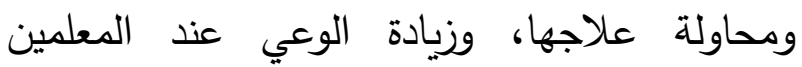
بأهميتها لتطوير العمل، كما أظهرت أن للرقابة أنابة
حدوث الأخطاء، ووضع الخطط العلاجية الملائمة، والتأكد من أن العمليات الفنية تسير وفق الخطط وفط النط الموضوعة، والتأكد من حسن استغلال الموارد

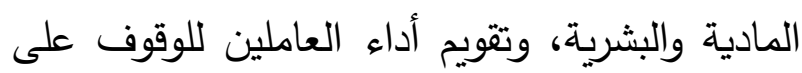
درجة كفايتهم وقدراتهم، وإعداد برامج لتطوير أدائهح ومهاراتهم وقدراتهم.

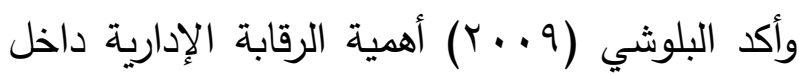

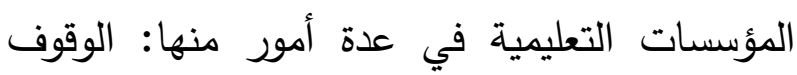
على المشكلات والمعوقات التي تواجه العملية التربوية والأكاديمية التي تؤثر في جودة العملية التدريسية، والتأكد من أن المخصصات المالية تنفق

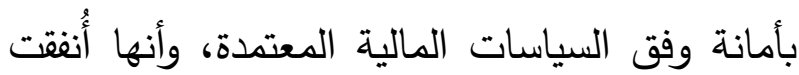

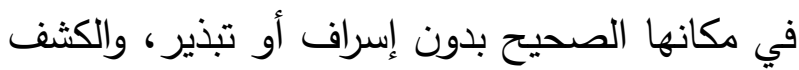
عن أماكن الخطأ والانحراف ومعالجتها، والتأكد من ونان تفعيل الحقوق والمزايا المقررة للعاملين.

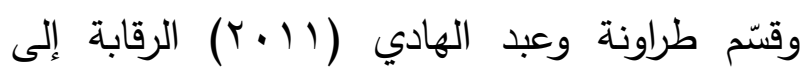
قسمين هما: الجانب الإداري: ويتعلق بالجوانب

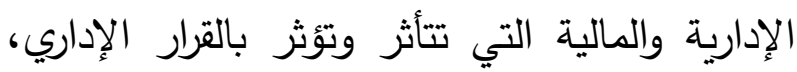

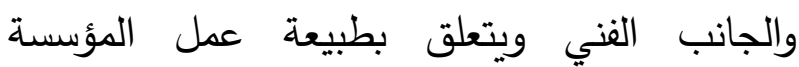

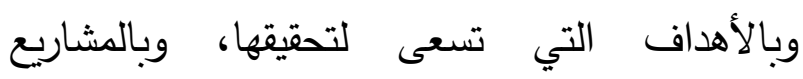

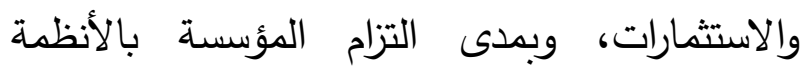
والقوانين واللوائح وسير العمل. zhang, ) واتتق كل من اريك (eric, 2008) وزانغ ولنير 2008) بأن للرقابة الإدارية أثرًا على حيوية وإنتاجية الأداء التدريسي والسلوكي للمعلمين، فهي وسيلة مهمة لمتابعة سير العمل، وتحفيزهم لتقديم أفضل ما لأبل 
من (70) معلماً ومعلمة مستخدمةً المنهج الوصفي

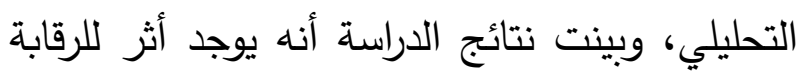

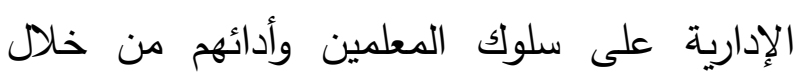
الحصص الصفية بشكل إيجابي أو سلبي، كما بيّت

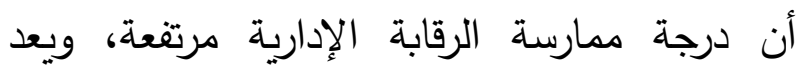
الإشراف الإداري في مقدمة الوسائل الرقابية لاعتماده

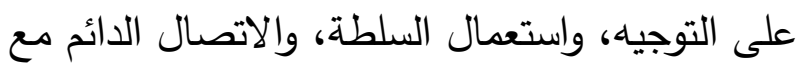
المعلمين، وتحفيزهم والثناء على أدائهم.

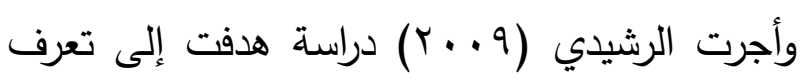
أثر وحدات الرقابة الإدارية الداخلية في الجامعات

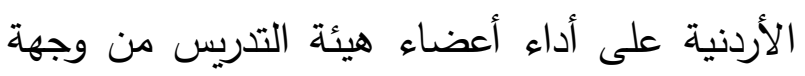

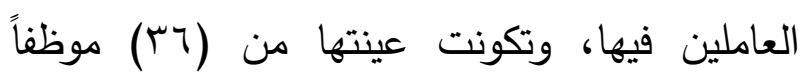
وموظفة مستخدمةً المنهج الوصفي التحليلي، وبينت

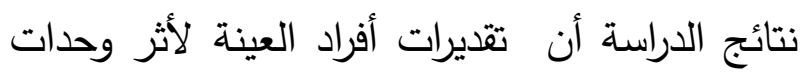
الرقابة الإدارية الداخلية في الجامعات الأردنية على لإنى لإنى

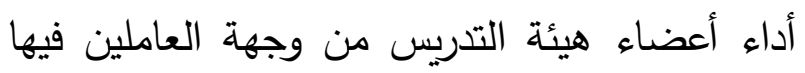
تراوح من تقدير (ضعيف) إلى تقدير (متوسط)، وبينت أيضًا أن درجة ممارسة الرقابة الإدارية مرتفعة، كما أظهرت وجود فروق ذات دات دلالة إحصائية في تقديرات أفراد العينة تعزى إلى متغير المؤهل لصالح البكالوريوس، ومتغير مكان الجامعة

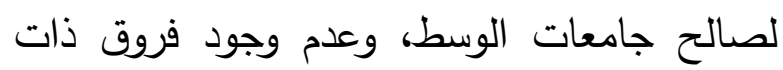
دلالة إحصائية في تقديرات أفراد العينة تعزى إلى وجلى تروفي دان متغير الخبرة.

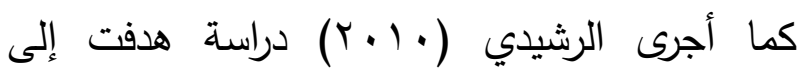

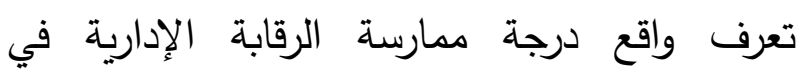

الإدارية أثراً في توزيع الإشراف المدرسي على جميع المعلمين بالمدرسة وفق جدول زمني عادل لتوضيح الجوانب الإيجابية والسلبية في العمل، ومقارنة ذلك بلك في التقرير الذاتي للمعلم، ومشاركة الموجه في إعداد تقرير تقويم المعلم السنوي وفق خطة مرسومة للمتابعة خلال الفصل الدراسي. وفي دراسة الكوفحي (2005) التي هدفت إلى الى التى التئ التعرف على الرقابة الإدارية وأثرها في الأداء الوظيفي للعاملين في مديريات التربية والتعليم في

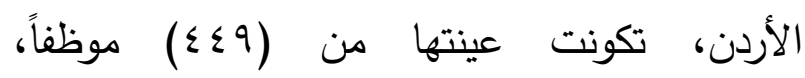
واستخدمت المنهج الوصفي، وبينت نتائج الدراسة وجود أثر للرقابة الإدارية على مجالي الثفافية والحوافز والمكافآت، وعلى الأداء الوظيفي الفعال الدال بدرجة كبيرة. أما دراسة كارثريسي (Carruthersy, 2008) التي كيرة، هدفت إلى الكثف عن الرقابة الإدارية وعلاقتها برفع درجة الروح المعنوية في المدارس الحكومية والخاصة، فقد أجريت على عينة مكونة من (00)

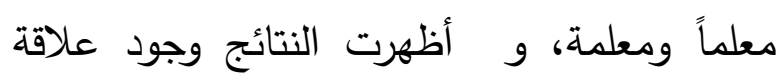
طردية بين الرقابة الإدارية في المدرسة وزيادة فعالية

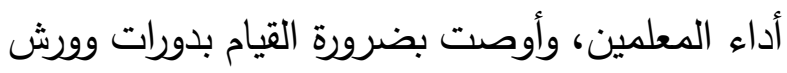
توعوية للمعلمين والمشرفين التربويين لزيادة أهمية الرقابة الذاتية لديهم.

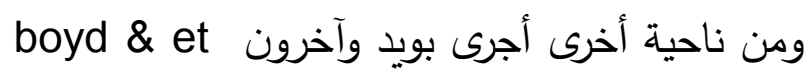

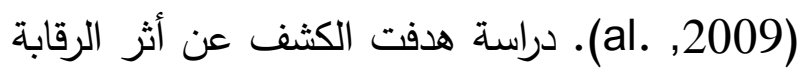
الإدارية على سلوك وأداء المعلمين، فتكونت عينتها 
الددارس الحكومية الثانوية في منطقة حائل من الرقابة الإدارية لدى مديري المدارس الحكومية

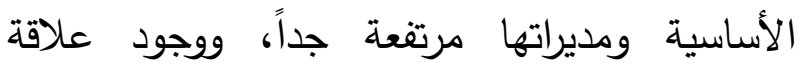
ارتباطية إيجابية بين الرقابة الإدارية والأداء الوظيفي

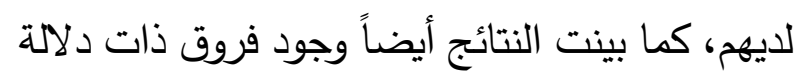
إحصائية عند مستوى الدلالة (1) متوسطات استجابات أفراد عينة الدراسة نحو فاعلية الرقابة الإدارية لدى مديري المدارس الحكومية

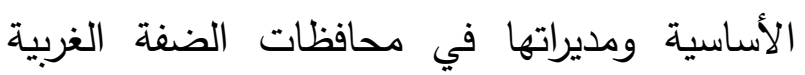
تعزى إلى متغير الجنس لصالح الذكور ، وعدم وجود فروق ذات دلالة إحصائية تعزى لـتغيرات (المؤهل

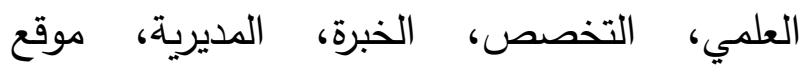
المدرسة).

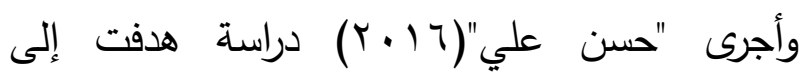
التعرف على الرقابة الإدارية وعلاقتها بالأداء الوظيفي لدى مديري المدارس الحكومية الأساسية في محافظات شمال الضفة الغربية من وجهات نظر لنائر المديرين أنفسهم، وتكونت عينتها من (Y ( T) مديراً ومديرة مستخدمةً المنهج الوصفي التحليلي، وبينت

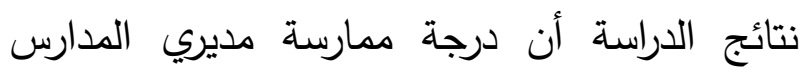

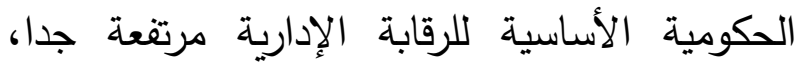
ووجود علاقة ارتباطية إيجابية بين الرقابة الإدارية

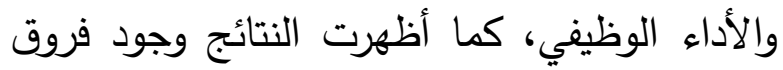

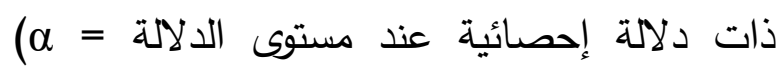
(0.05بين متوسطات درجة تطبيق مديري المدارس

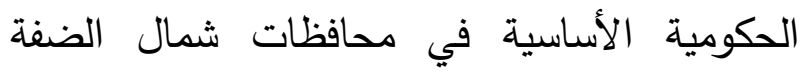
الغربية للرقابة الإدارية تعزى إلى متغير الجنس وجهة نظر المعلمين، وتكونت عينتها من (TOب)

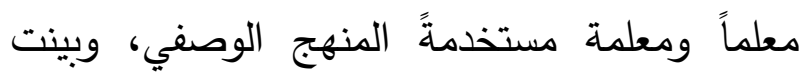
نتائج الدراسة أن درجة ممارسة الرقابة الإدارية مرتفعة، كما بينت وجود فروق ذات دلالة إحصائية عند مستوى الدلالة (0.05=0 م) في درجة ممارسة الرقابة الإدارية تعزى إلى متغير الجنس لصالح

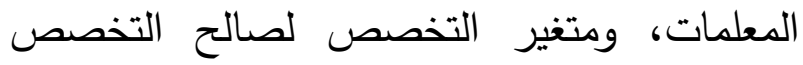

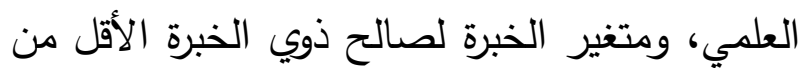
ه سنوات، والخبرة الأكثر من • ( سنوات.

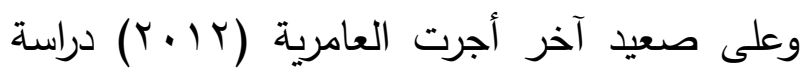
هدفت إلى تقديم تصور مقترح للرقابة الإدارية على

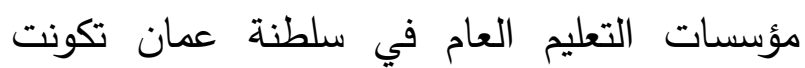
عينتها من (roך) موظفاً وموظفة من جميع

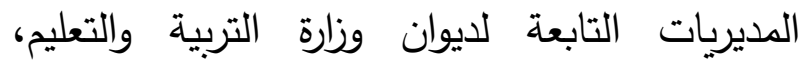
واستخدمت المنهج الوصفي التحليلي، وبينت نتائج

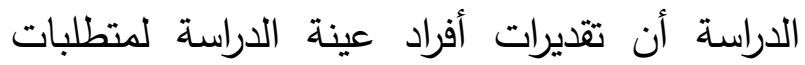
الرقابة الإدارية وآلياتها في مؤسسات التعليم العام مرتفعة. - مركا

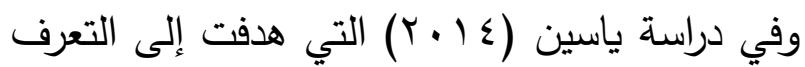
على درجة فاعلية الرقابة الإدارية، ودرجة تطبيق الأداء الوظيفي لاى مديري المدارس الحكومية الأساسية ومديراتها في محافظات الضفة الغربية من لأن وجهة نظر المعلمين، تكونت عينة الدراسة من

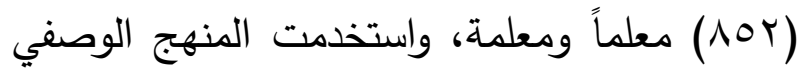
الارتباطي، وبينت نتائج الدراسة أن درجة فاعلية 
وعدم وجود فروق ذات دلالة إحصائية تعزى لمتغيرات (الخبرة، والمؤهل العلمي).

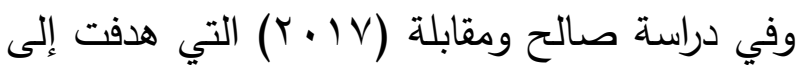
تعرف درجة تطبيق مديري المدارس الثانوية الحكومية والخاصة للرقابة الإدارية من وجهة نظر لنرائر المعلمين، تكونت عينة الدراسة من (Y (Y) معلماً ومعلمة، واستخدت المنهج الوصفي، وبينت النتائج أن درجة تطبيق مديري المدارس الثانوية الحكومية والخاصة في محافظة العاصمة عمّان للرقابة الإدارية عالية، كما أظهرت النتائج وجود فروق ذات دلالة إحصائية عند مستوى الدلالة (م=0.05 بين متوسطات درجة تطبيق مديري المدارس الثانوية العامة والخاصة من وجهة نظر المعلمين تعزى إلى

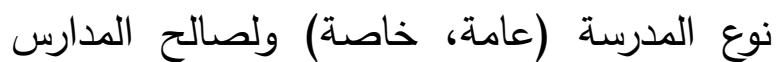

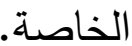

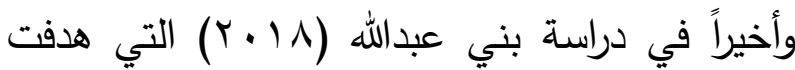
إلى تعرف درجة ممارسة مديري المدارس الثانوية الحكومية للرقابة الإدارية وعلاقتها بالالتزام التتظيمي من وجهة نظر المعلمين، تكونت عينة الدراسة من

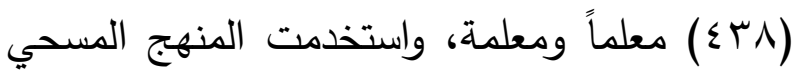
الارتباطي، وأظهرت النتائج أن درجة ممارسة مديري المدارس الثانوية الحكومية للرقابة الإدارية متوسطة، وأن مستوى الالتزام التنظيمي متوسط، بالإضافة إلى وجود علاقة ارتباطية إيجابية بين الرقابة الإدارية

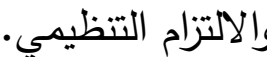

لصالح الذكور، وعدم وجود فروق ذات دلالة إحصائية تعزى لمتغيرات (الخبرة، والمؤهل العلمي،

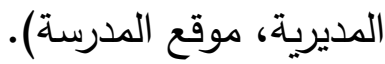

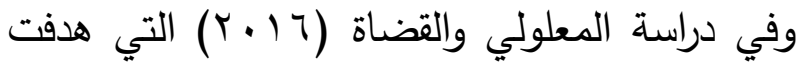
إلى تعرف درجة ممارسة مديري المدارس للرقابة

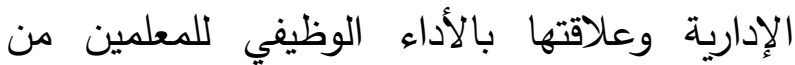
وجهة نظر المديرين والمعلمين في سلطنة عمان،

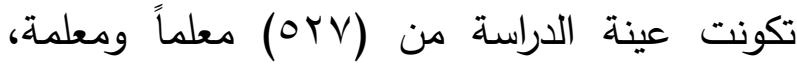
و(97) مديرا ومديرة، واستخدمت المنهج الوصفي الارتباطي، وبينت النتائج أن درجة ممارسة مديري

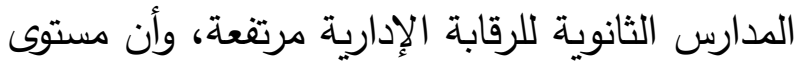
الأداء الوظيفي للمعلمين كان بدرجة مرتفعة، بالإضافة إلى وجود علاقة ارتباطية إيجابية بين ممارسة الرقابة الإدارية ومستوى الأداء الوظيفي

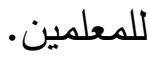

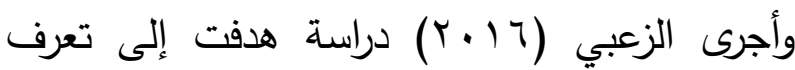
أساليب الرقابة الإدارية لدى مديري المدارس الثانوية

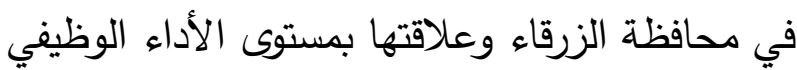

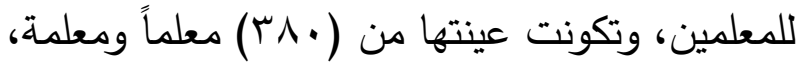
واستخدمت المنهج الوصفي الارتباطي، وأظهرت النتائج أن درجة تطبيق أساليب الرقابة الإدارية لاى الدئ مديري المدارس الثانوية في محافظة الزرقاء مرتفعة، وأن مستوى الأداء الوظيفي للمعلمين كان بدرجة مرتفعة أيضًا، كما أظهرت النتائج وجود فروق ذات التوني دلالة إحصائية في درجة تطبيق مديري المدارس الثانوية للرقابة الإدارية تعزى إلى متغير الجنس، درجيه 
الجهد المتواصل لتحقيق أداء عالٍ في العملية التدريسية والادارية.

ومن هنا تأتي أهمية هذه الدراسة في تعرف درجة

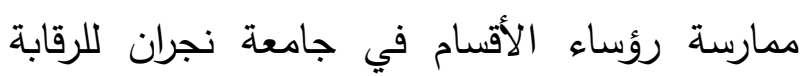

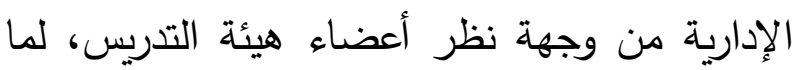
لها من أهمية في تحقيق الأهداف المنشودة والمخطط

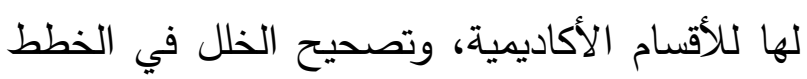

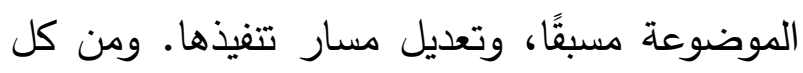
ما تقدم كان شعور الباحث بمشكلة هذه الدراسة. مشكلة الدراسة: تعدّ الرقابة الإدارية من أهم عناصر العملية الإدارية في أي مستوى إداري، فهي أداة لقياس درجة أداء المنظمات للمهام والأنشطة المختلفة، ومدى قدرتها على تحقيق أهدافها، وهي عملية مخططة ومنظمة تهدف إلى وضع معايير للأداء لأوجه النشاطات

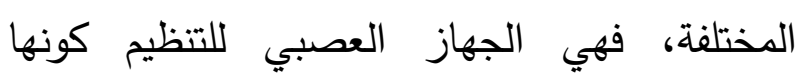
تتعرض لكل خلية من خلاياها تتأثر بها وتؤثر فيها

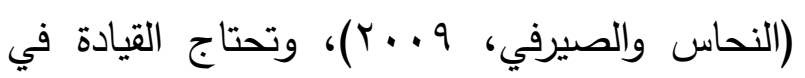
المؤسسات التربوية إلى مواصفات وكفايات فنية وإدارية لا بد أن يتمتع بها القائد لكي يكون قادراً

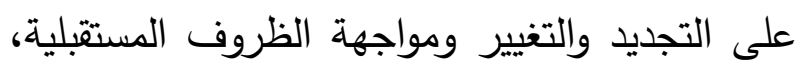
وتحديد المشكلات بدقة وإيجاد الحلول المناسبة لها. فالرقابة من المهام الرئيسية للقائد التربوي، وهي

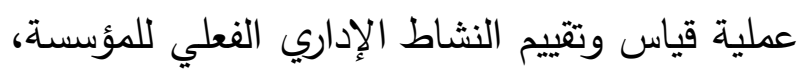

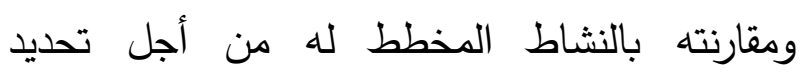

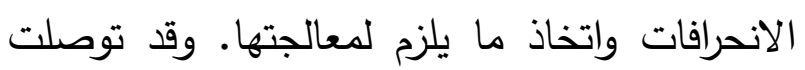

وممّا مضى يمكن القول إنّ الرقابة الإدارية: عملية

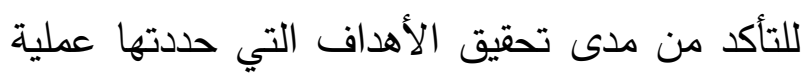

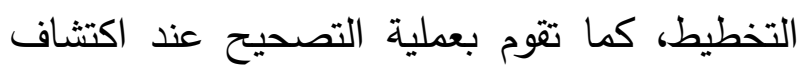
أي خلل في الخطط الموضوعة مسبقًا، وتصحيح مسار التنفيذ، فهي لا تُعنى بمعالجة الأخطاء

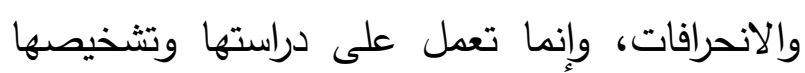

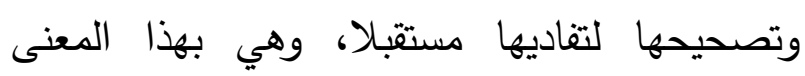
تساعد في التحقق من أداء الأنشطة وفق ما هو محدد له من معايير ومؤشرات، كما تعد الرقابة

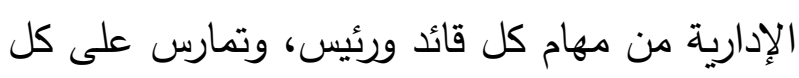
المهام والوظائف في المنظمة، فهي ليست وظيفة مستقلة ومنفصلة عن الوظائف الإدارية الأخرى، حيث إن وظيفة التخطيط نفسها تحتاج إلى رقابة، وكذلك التنظيم والقيادة، وعلى ذات المنوات إنهات وظيفة الرقابة تحتاج إلى تخطيط وتتظيم حتى تتم على أكمل وجه من خلال وضع نظام رقابي سليم

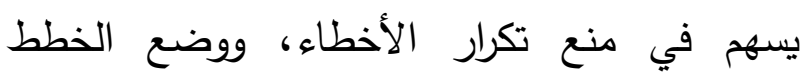
العلاجية الملائمة، والتأكد من حسن استغلال الموارد

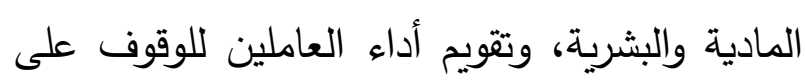
درجة كفايتهم، وتحديد المشكلات التي يعانون منها والعمل على حلها، والعمل على بناء علاقات جيدة وتفاعلية مع الأعضاء لكسبهم مزيداً من الثقة في ولثي علئ

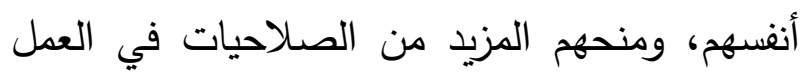

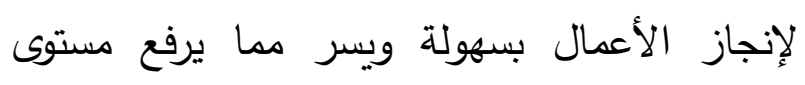

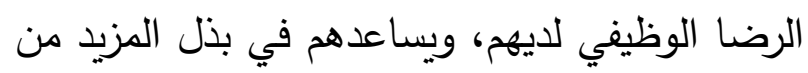


1- ما درجة ممارسة رؤساء الأقسام في جامعة نجران للرقابة الإدارية من وجهة نظر أعضاء هيئة رونساء

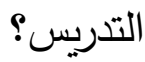
r- هل توجد فروق دالة إحصائياً عند مستوى دلالة ( $\alpha$ بين متوسطات تقديرات أفراد العينة

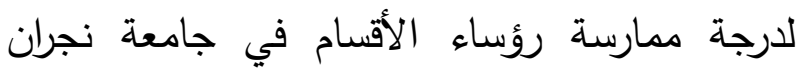

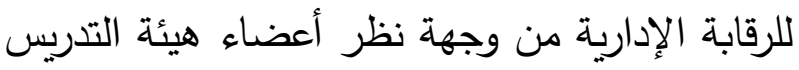
تعزى لتأثير متغيرات (الجنس، الخبرة التدريسية، القسم، الرتبة الأكاديمية)؟ تعزيرات أهداف الدراسة: تسعى هذه الدراسة إلى: 1- تسليط الضوء على واحدة من أبرز القضايا التربوية الجامعة بين إحدى أهم وظائف العملية

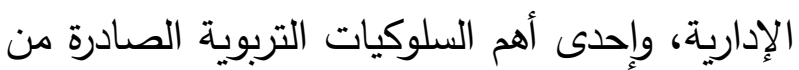
قبل القادة والمدراء في المؤسسات التربوية والتعليمية،

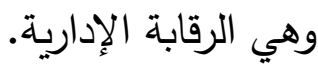
r- التعرف على درجة ممارسة رؤساء الأقسام في جامعة نجران للرقابة الإدارية من وجهة نظر أعضاء

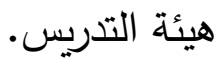
r- التعرف على الاختلاف في درجة ممارسة رؤساء الأقسام في جامعة نجران للرقابة الإدارية من دن التهات وجهة نظر أعضاء هيئة التدريس وفقا لتأثير متغيرات

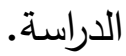

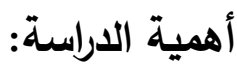
تظهر أهمية الدراسة فيما يلي:

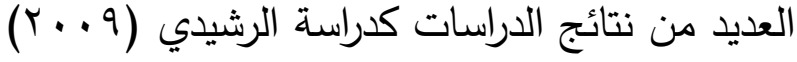
ودراسة ياسين (؟1 (Y) ودراسة المعلولي والقضاة

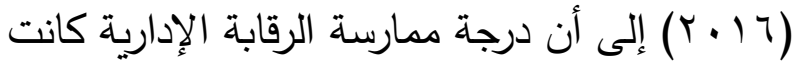

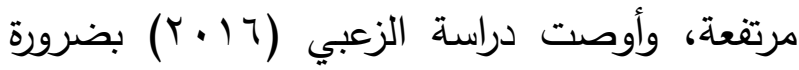

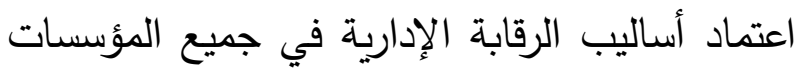
التزبوية، وعدم اقتصارها على المدراس فقط، وتثجيع القادة في الميدان التربوي على ممارسة الرقابة الإدارية لتأثيرها الفاعل على مستوى أداء العاملين فيها. ومن خلال عمل الباحث في جامعة نجران، واطلاعه على الدراسات السابقة، لم يجد أي دراسة تبحث في مدى ممارسة رئيس القسم للرقابة الإدارية باعتباره قائدًا في مؤسسة أكاديمية وله عدة مهام، وتقع على ملى لئه عاتقه مسؤولية كبيرة في متابعة قسمه الأكاديمي من ون ونه أجل تحديد الانحرافات والمشكلات وتعديل مسارها،

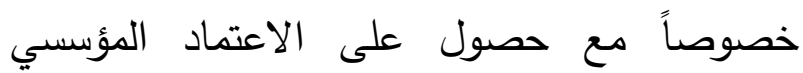
ونطلعها للحصول على الاعتمادات البرامجية. لذا سعت هذه الدراسة لتحديد مدى ممارسة رؤساء الأقسام بجامعة نجران للرقابة الإدارية انطلاقًا من لنال

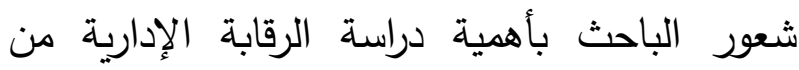
وجهة نظر أعضاء هيئة التدريس للوقوف على الواقع لئح

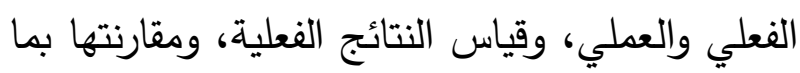
هو مخطط له، وتثخيص أسباب الانحرافات وتحليلها، وتوجيهها نحو المسار الصحيح، ومن هنا

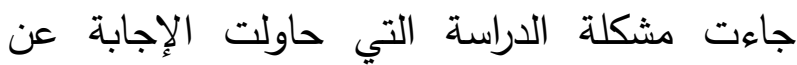

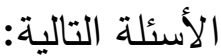


- الحدود الزمنية: طبقت هذه الدراسة خلال الفصل

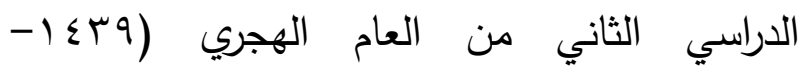
. (ه) 1 ( ) - الحدود البشرية: اقتصرت الدراسة على أعضاء هيئة التدريس في جامعة نجران. التعريفات الاصطلاحية والإجرائية: الرقابة الإدارية: "العملية التي من خلالها يتأكد

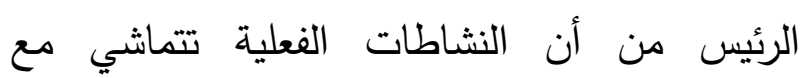

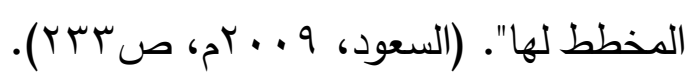
الرقابة الإدارية (إجرائياً): العملية التي يستطيع من التهان خلالها رئيس القسم التأكد من سير العمل داخل التحانل

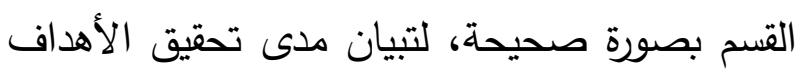

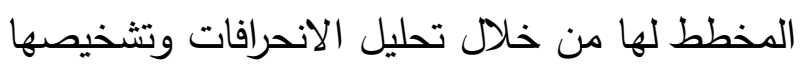
ومعالجتها للوصول بالقسم إلى أكبر كفاءة ممكنة،

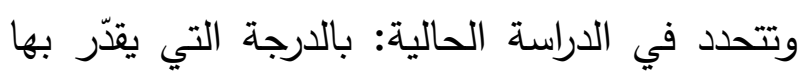
أعضاء هيئة التدريس ممارسة رئيس القسم للرقابة

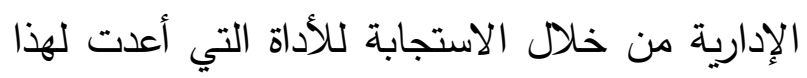

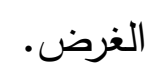

رئيس القسم: هو المسئول عن أداء مجموعة من

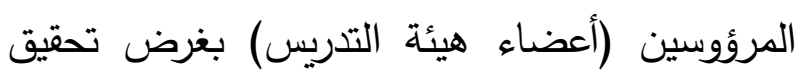

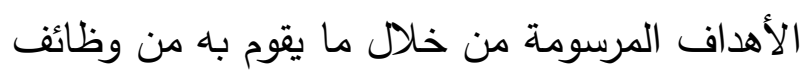

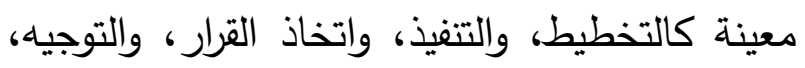

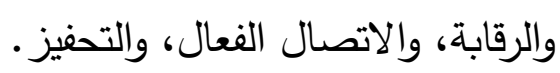
أعضاء هيئة التدريس: هم الهيئة التدريسية الذين والهال يحملون مختلف الدرجات العلمية والرتب، ويدرّسون
1- الدور الذي تؤديه الرقابة الإدارية كوسيلة من

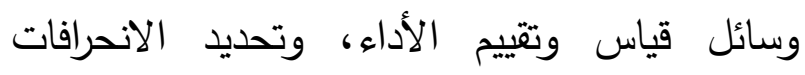
وتثخيصها وتصحيح مسارها. r- تقيد الدراسة في إثراء المكتبة العربية، وتزويد الباحثين بأطر نظرية حول درجة ممارسة رؤساء

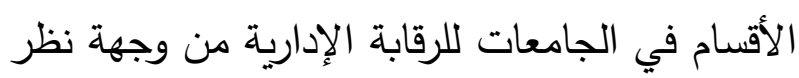
أعضاء هيئة التدريس. ب- الإسهام في توعية رؤساء الأقسام في الجامعات السعودية بأهمية الرقابة الإدارية في العملية الإدارية. ع- قلة الدراسات والبحوث في المملكة العربية السعودية - على حد علم الباحث - التي تتاولت درجة ممارسة رؤساء الأقسام في الجامعات السعودية

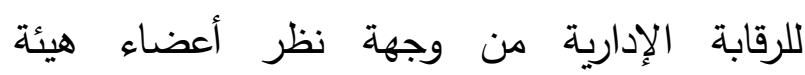
التدريس. 0- يمكن أن تفيد نتائج هذه الدراسة القائمين على التعليم ومتخذي القرار بضرورة تفعيل أساليب الرقابة الإدارية في المؤسسات التربوية، ودورها في تحسين الواقع العملي والتدريسي. حدود الاراسة: تقتصر هذه الدراسة في حدودها على ما يلي: - الحدود الموضوعية: معرفة درجة ممارسة رؤساء الأقسام في جامعة نجران للرقابة الإدارية من وجهة دمانة نظر أعضاء هيئة التدريس. - الحدود المكانية: أجريت الدراسة على كليات

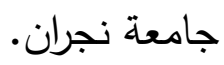


تكوّن مجتمع الدراسة من جميع أعضاء هيئة

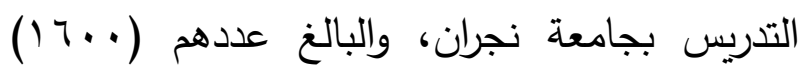

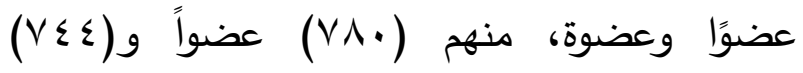

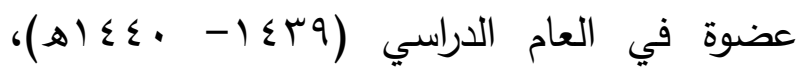
وذلك بحسب إحصائيات عمادة شؤون أعضاء هيئة التدريس والموظفين في جامعة نجران، وتكوّنت عينة

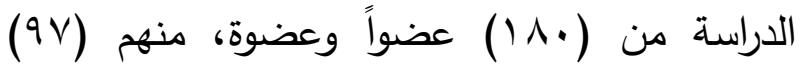
عضواً و(r)) عضوة، تم اختيارهم بالطريقة العشوائية البسيطة، ويوضح الجدول (1) توزيع عينة الدراسة بحسب متغيرات الدراسة.
في مختلف التخصصات في كليات جامعة نجران

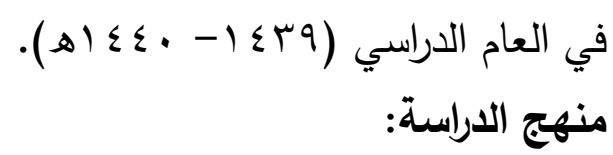
يعتمد على دراسة الظاهرة في الواقع ووصفها وتحليلها، والتعبير عنها كماً وكيفاً من خلال رصد واقع المشكلة البحثية وتحليلها لتبيان درجة ممارسة رؤساء الأقسام في جامعة نجران للرقابة الإدارية من لنه وجهة نظر أعضاء هيئة التدري. مجتمع الاراسة وعينته:

\begin{tabular}{|c|c|c|c|}
\hline النسبة المئوية & التكرار & الفئات & المتغير \\
\hline 53.9 & 97 & ذكور & \multirow{2}{*}{ الجنس } \\
\hline 46.1 & 83 & إناث & \\
\hline 11.7 & 21 & أقل من ه سنوات & \multirow{3}{*}{ الخبرة التدريسية } \\
\hline 48.3 & 87 & o سنوات إلى • ( سنوات & \\
\hline 40.0 & 72 & • ـ اسنوات فأكثر & \\
\hline 72.2 & 130 & إنساني & \multirow{2}{*}{ القسم } \\
\hline 27.8 & 50 & علمي & \\
\hline 24.4 & 44 & محاضر & \multirow{4}{*}{ الرتبة الأكاديمية } \\
\hline 58.3 & 105 & أستاذ مساعد & \\
\hline 11.7 & 21 & أستاذ مشارك & \\
\hline 5.6 & 10 & أستاذ دكتور & \\
\hline
\end{tabular}

الجدول (1): توزيع أفراد عينة الدارسة بحسب متغيرات الدراسة.

و(7 (1) فقرة في المجال الفني من خلال الاستعانة

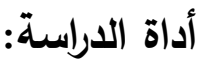
بالدراسات السابقة التالية: دراسة المعلولي والقضاة من أجل بناء أداة الدراسة تم الرجوع إلى الدراسات

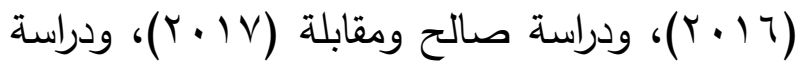

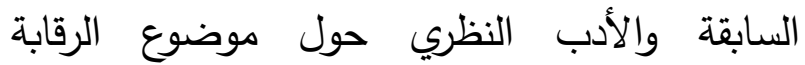

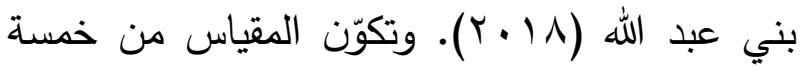
الإدارية، وتم تصميم المقياس من قبل الباحث وتكون بدائل في الإجابة تم تصحيحها بإعطاء الفقرات من (דr) فقرة، منها (•r) فقرة في المجال الإداري 
الدرجات (1-r-r-§-0)، ولتحديد مستويات والإدارة التربوية، وطرق التدريس، وعلم النفس

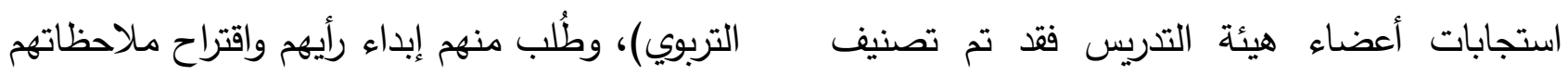

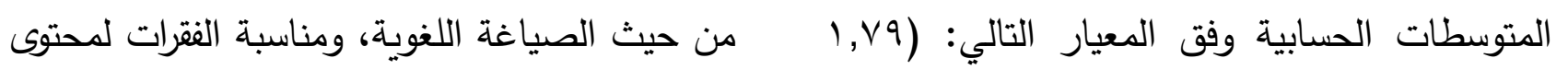

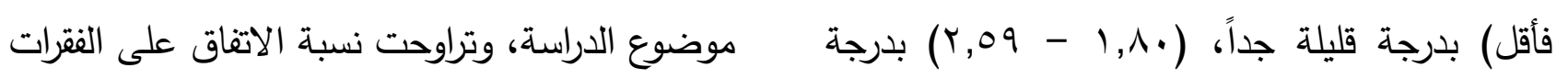

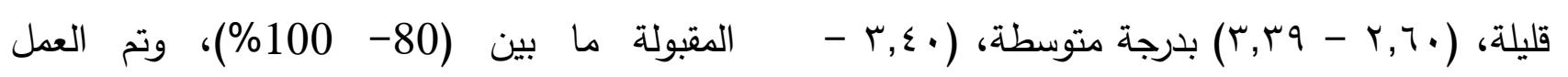

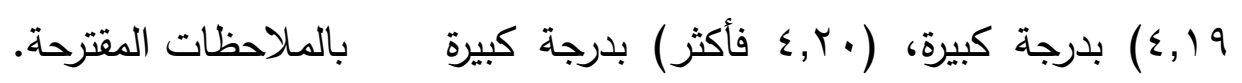
ثبات الأداة: للتحقق من ثبات أدوات الدراسة، فقد تم جداً. صدق الأداة: للتحقق من صدق أداة الدراسة، تم استخدام معامل كرونباخ ألفا كما هو موضح في لات لدات

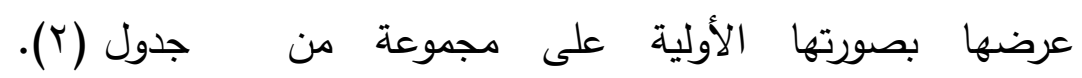

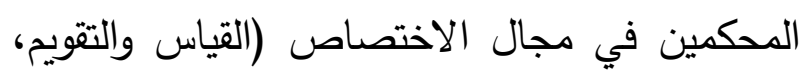
جدول (ץ): قيم معامل ثبات الاتساق الداخلي لأدوات الدراسة ومجالاتها.

\begin{tabular}{|c|c|}
\hline معامل الثبات & المجالات \\
\hline 0.88 & المجال الإداري \\
\hline 0.84 & المجال الفني \\
\hline 0.92 & الكلي ل الي \\
\hline
\end{tabular}

وتم استخدام معامل كرونباخ ألفا لحساب ثبات أداة - المتوسطات الحسابية والانحرافات المعيارية للفقرات والمجالات.

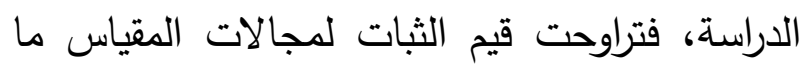
- تحليل التباين للكثف عن الفروق بين متغيرات الدراسة. نتائج الدراسة ومناقثتها: السؤال الأول: ما درجة ممارسة رؤساء الأقسام في

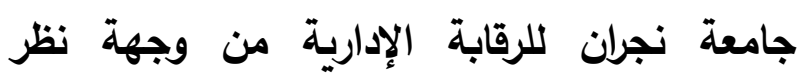
أعضاء هيئة التدريس؟ للإجابة عن هذا السؤال تم الإنه حساب الأوساط الحسابية والانحرافات المعيارية والرتب، ويتبين ذلك من خلال الجدول (r). بين (0.84) و (0.88)، بينما في مقياس الرقابة

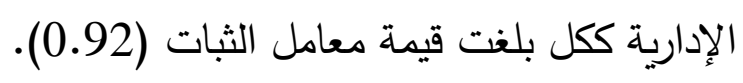
الأساليب الإحصائية: تم استخدام الأساليب الإحصائية التالية: - التكرارات والنسب المئوية لتحديد توزيع عينة الإسابل

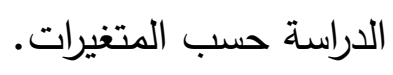
- معامل كرونباخ ألفا لحساب ثبات الاتساق الات الات

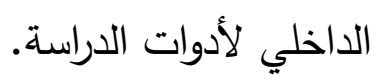


جدول (ץ): المتوسطات الحسابية والانحرافات المعيارية والرتب لارجة ممارسة رؤساء الأقسام في جامعة نجران للرقابة الإدارية من وجهة نظر أعضاء هيئة التدريس على جميع المجالات والفقرات.

\begin{tabular}{|c|c|c|c|c|c|}
\hline درجة الممارسة & 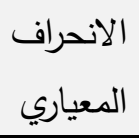 & الحسابي & المجالات والفقرات & الرتبة & م \\
\hline & & & المجال الإداري & & \\
\hline كبيرة & 0.818 & 4.16 & يتابع شؤون مجلس القسم العلمية وينفذ قراراته. & 1 & 1 \\
\hline كبيرة & 1.076 & 4.12 & يعد السجلات الخاصة بتقييم أداء أعضاء هيئة & r & IT \\
\hline كبيرة & 0.977 & 4.11 & يقوم بتشكيل اللجان العلمية بالقسم. & r & $1 \varepsilon$ \\
\hline كبيرة & 0.962 & 4.03 & الأسرف على إعداد الخطة الاستراتيجية للقسم وفق التخطيط. & $\varepsilon$ & r \\
\hline كبيرة & 1.179 & 3.97 & يتابع الأمور المتعلقة بالاستعداد للعام الدراسي. & 0 & $r$. \\
\hline كبيرة & 1.065 & 3.97 & يشرف على رفع مستوى الجودة وتطوير مخرجاتها. & 7 & $\varepsilon$ \\
\hline كبيرة & 1.108 & 3.96 & يشرف على إعداد التقرير السنوي للقسم. & v & 10 \\
\hline كبيرة & 1.051 & 3.92 & الكلية مابع يفوض إليه من صلاحيات من قبل عميد & $\wedge$ & $r$ \\
\hline كبيرة & 1.107 & 3.91 & يتابع التزام أعضاء هيئة التدريس بالساعات & 9 & $\pi$ \\
\hline كبيرة & 1.171 & 3.88 & المحاضرات. & 1. & iv \\
\hline كبيرة & 0.967 & 3.86 & وخارجها. & 11 & r \\
\hline كبيرة & 1.119 & 3.81 & يقيم عمل اللجان وفق معايير واضحة. & ir & 17 \\
\hline كبيرة & 1.095 & 3.78 & يتابع أسس التشكيلات الطلابية ( قبول، تشعيب). & ir & 1. \\
\hline كبيرة & 1.112 & 3.73 & يزود الأعضاء بتغذية راجعة حول أدائهم. & $1 \varepsilon$ & $\mathrm{v}$ \\
\hline كبيرة & 1.21 & 3.67 & يحدد احتياجات القسم من أعضاء هيئة التدريس من & 10 & $q$ \\
\hline كبيرة & 1.181 & 3.63 & والمالية. متطلبات القسم التعليمية والبحثية والإدارية & 17 & 0 \\
\hline 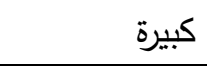 & 1.316 & 3.58 & يتابع احتياجات القسم من اللوازم والأثاث. & iv & 11 \\
\hline
\end{tabular}


هادي سالم العجمي

\begin{tabular}{|c|c|c|c|c|c|}
\hline كبيرة & 1.244 & 3.48 & | يناقش الخطة الاستراتيجية مع أعضاء هيئة التدريس & 11 & 7 \\
\hline متوسطة & 1.391 & 3.34 & لرواتب، إجازات، ترقيات). أعضاء هيئة التدريس المختلفة( & 19 & 11 \\
\hline \multirow[t]{2}{*}{ قليلة } & 0.401 & 2.20 & | يعد ميزانية سنوية للقسم وفق الإمكانات المتاحة. & r. & 19 \\
\hline & & & | المجال الفني & & \\
\hline 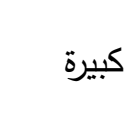 & 1.112 & 3.91 & 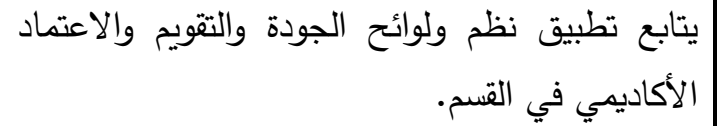 & 1 & r) \\
\hline كبيرة & 1.17 & 3.82 & يتابع التزام أعضاء هيئة التدريس بتوصيف المقررات. & r & rt \\
\hline 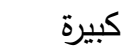 & 1.136 & 3.8 & | يتابع سير الاختبارات الشهرية في القسم. & r & ry \\
\hline كبيرة & 1.153 & 3.79 & يتابع سير المقررات الدراسية لأعضاء هيئة التدريس. & $\varepsilon$ & rᄉ \\
\hline 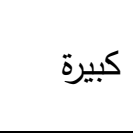 & 1.207 & 3.76 & 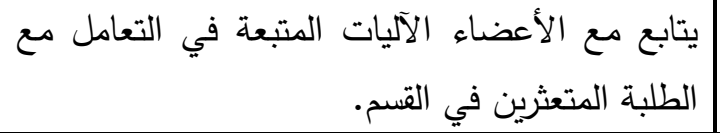 & 0 & ru \\
\hline 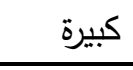 & 1.231 & 3.68 & يشرف على عملية التطوير الأكاديمي لبرامج القسم. & 1 & r. \\
\hline كبيرة & 1.303 & 3.67 & لديه برامج هادفة لتفعيل العلاقة مع المجتمع المحلي. & V & $r \varepsilon$ \\
\hline كبيرة & 1.306 & 3.64 & ليقدم أفكاراً ابداعية غير تقليدية تهدف لتطوير القسم. & $\wedge$ & rr \\
\hline 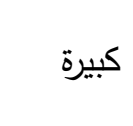 & 1.144 & 3.63 & | وقدرات الطلبة مدى مواءمة الاختبارات للمقررات الدراسية & 9 & rt \\
\hline كبيرة & 1.098 & 3.58 & | يتابع النشاط البحثي لأعضاء هيئة التدريس. & $1 \cdot$ & rV \\
\hline 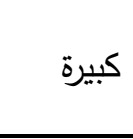 & 1.299 & 3.58 & | يشرف على تنفيذ أنشطة لا صفية هادفة لطلبة & 11 & ro \\
\hline 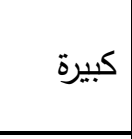 & 1.233 & 3.57 & | لمتابع التزام أعضاء هيئة التدريس بخطط تحسين & ir & $r \varepsilon$ \\
\hline كبيرة & 1.359 & 3.54 & يشرف على مختلف النشاطات الطلابية بالقسم. & ir & r \\
\hline 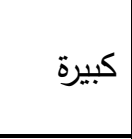 & 1.432 & 3.51 & 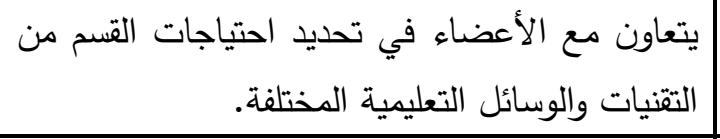 & $1 \varepsilon$ & rq \\
\hline كبيرة & 1.286 & 3.43 & | يحدد احتياجات أعضاء هيئة التدريس المهنية. & 10 & 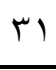 \\
\hline متوسطة & 1.308 & 3.34 & يضع برامج تحفيزيـة للطلبة المتفوقين. & 17 & ro \\
\hline
\end{tabular}


متطلبات القسم واحتياجاته. أما في المجال الفني فتراوحت المتوسطات الحسابية لفقرات هذا المجال ما فالهات بين (3.34-3.91)، أي ما بين درجة متوسطة إلى الى

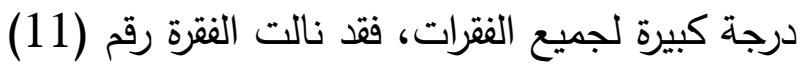
ونصها " يتابع تطبيق نظم ولوائح الجودة والتقويم الإنيم والاعتماد الأكاديمي في القسم" على المرتبة الأولى لكي بمتوسط (3.91) وبدرجة كبيرة، وهذا يدل على فلى الألى عناية رئيس القسم بتطبيق معايير الجودة في رفع كفاءة العاملين بالقسم، والارتقاء بالمستوى المعرفي والمهاري والنفسي للطلاب، وتطوير المخرجات التعليمية وتحسينها، ونالت الفقرة رقم (r () ونصها" يضع برامج تحفيزية للطلبة المتفوقين" على الرتبة الأخيرة بمتوسط (3.34) وبدرجة متوسطة، وسبب لئب ذلك انثغال رئيس القسم بمتطلبات القسم ومشاكل عاتقه. الأعضاء والطلبة، وكثرة المهام الإدارية الملقاة على

يتضح من نتائج جدول (ץ) أن المتوسطات الحسابية

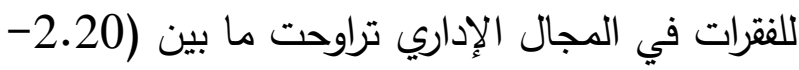
4.16)، أي ما بين درجة قليلة إلى درجة كبيرة، وقد الإدائ

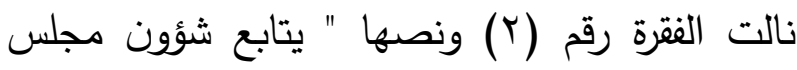
القسم العلمية وينفذ قراراته." على المرتبة الأولى كلى بمتوسط (4.16) وبدرجة كبيرة، وهذا يدل على الى أهمية شعور رئيس القسم بالمسؤولية تجاه القسم من

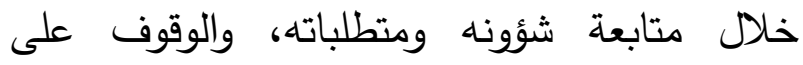
الشككلات مما ينعكس إيجابًا على سير العمل. بينما

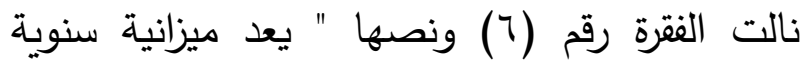
للقسم وفق الإمكانات المتاحة" على المرتبة الأخيرة بمتوسط (2.20) وبرجة قليلة، ويعود السبب في الإني ذلك إلى مركزية الأمور المالية في الجامعة لوجود وبعد

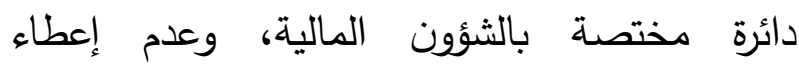
صلاحيات لرئيس القسم في هذه الأمور، فلا تتوفر

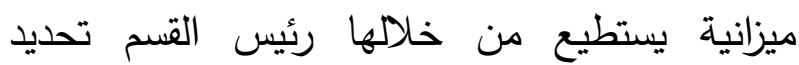
جدول (؛ ): المتوسطات الحسابية والانحرافات المعيارية والرتب للارجة ممارسة رؤساء الأقسام في جامعة نجران للرقابة الإدارية من وجهة نظر أعضاء هيئة التنريس لجميع المجالات والأداة الكلية.

\begin{tabular}{|c|c|c|c|c|c|}
\hline درجة الممارسة & الانحراف المعياري & المتوسط الحسابي & المجالات & الرقم & 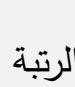 \\
\hline كبيرة & 0.887 & 3.75 & الدجال الإداري & 1 & 1 \\
\hline كبيرة & 1.107 & 3.64 & الدجال الفني & 2 & r \\
\hline كبيرة & 0.960 & 3.70 & لكلي الكي & & \\
\hline
\end{tabular}

الإداري في المرتبة الأولى وبدرجة كبيرة، ثم المجال الفني بالمرتبة الثانية وبدرجة كبيرة أيضًا، أما على الألى مستوى الأداة ككل: فجاءت درجة ممارسة رؤساء يتضح من نتائج جدول ( ) أن الكتوسطات الحسابية

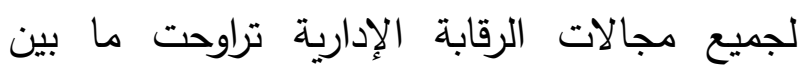

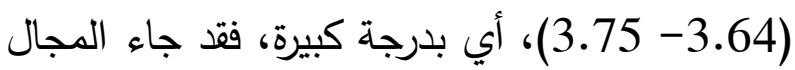


الأقسام في جامعة نجران للرقابة الإدارية كبيرة والتعليمية والإدارية، ويحقق أهدافها ورؤيتها

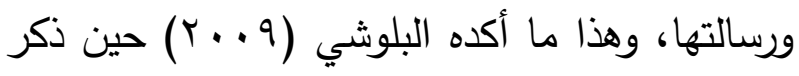
وبمتوسط بلغ (3.70).

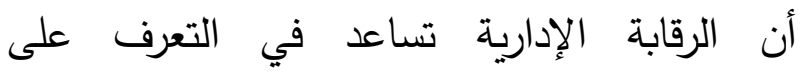
المشكلات والمعوقات التي تواجه العملية التربوية والأكاديمية وتؤثر في جودتها وتكثف عن والمبات أماكن

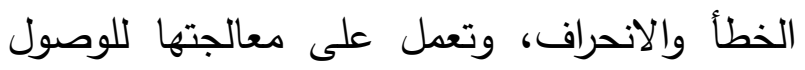

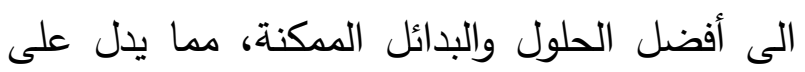
أن رؤساء الأقسام في جامعة نجران يتمتعون بقدرات

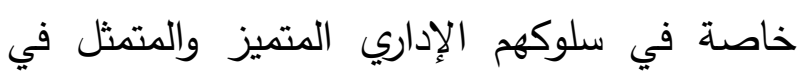

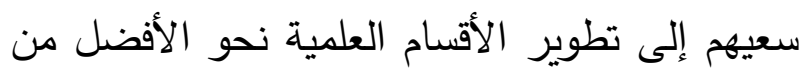

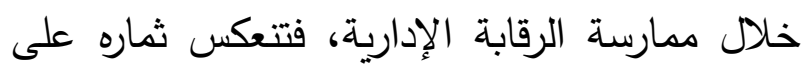
الأداء في الواقع. وقد اتفقت نتائج هذه الدراسة مع كل من: دراسة

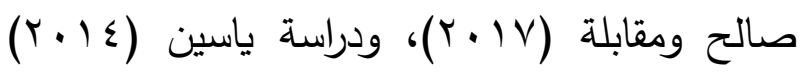
في أن درجة ممارسة الرقابة الإدارية كانت كبيرة، ودابة واختلفت مع نتائج كل من: دراسة بني عبد الله الله

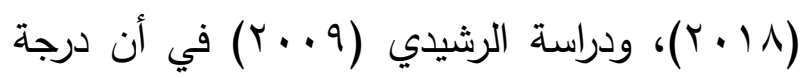
ممارسة الرقابة الإدارية كانت متوسطة.

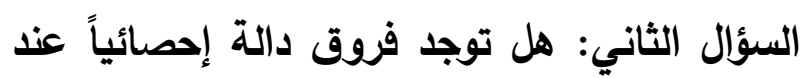

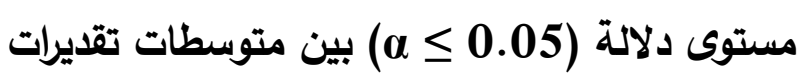

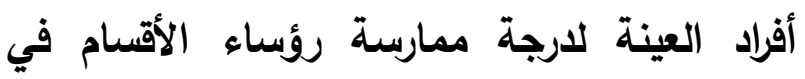

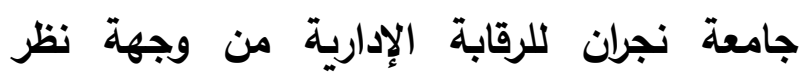
أعضاء هيئة التدريس تعزى لتأثير متغيرات

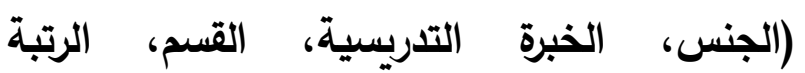
الأكاديمية)؟ للإجابة عن هذا السؤال تم استخراج

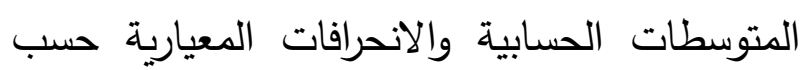
متغيرات الدراسة كما في الجدول (0).

ويعزو الباحث هذه النتيجة إلى أن جامعة نجران تعمل على تهيئة البيئة المناسبة لقيام رؤساء الأقسام بأدوارهم في ممارسة الرقابة في الجوانب الإدارية

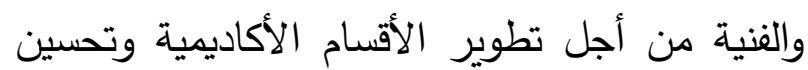
أدائها، وذلك من خلال منحهم الصلاحيات اللازمة لممارسة الرقابة والمتابعة، والقيام بالمسؤوليات والمهام الموكلة لرئيس القسم حسب ما ورابعة وردت في اللائحة المنظمة لتوصيف المهام والمسؤوليات

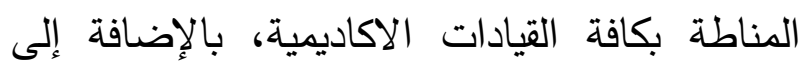

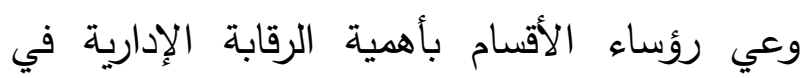

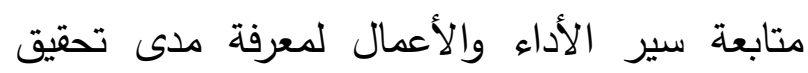
القسم للأهداف المرجوة، والاستخدام الأمثل للموارد المتاحة في القسم سواء كانت مادية أو بشرية، ومتابعة شؤون مجلس القسم العلمية، ومتابعة شؤون

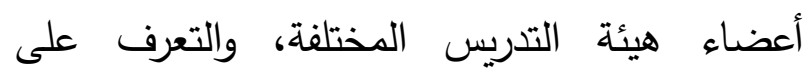
مشكلاتهم وآرائهم ومقترحاتهم واحتياجاتهم المهنية والأكاديمية والبحثية، فيتم تجنب العديد من السلبيات واتهات

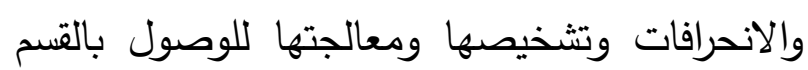
إلى أعلى درجة كفاءة ممكنة، فيولد عندهم عامل

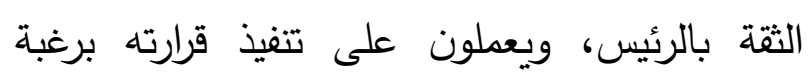

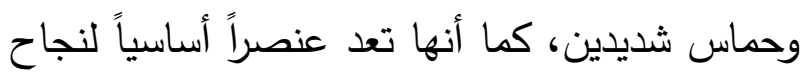
الأقسام العلمية في تأدية وظائفها، وتحقق أيضاً

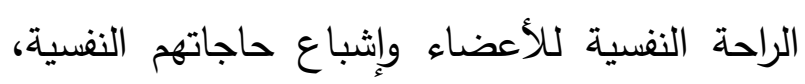

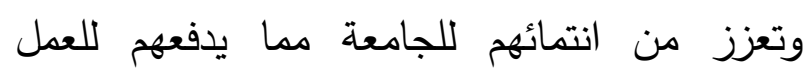

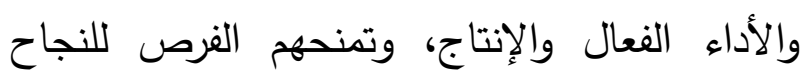

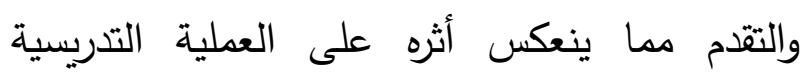


جدول (0): المتوسطات الحسابية والانحرافات المعيارية لدرجة ممارسة رؤساء الأقسام في جامعة نجران للرقابة الإدارية حسب متغيرات الاراسة

\begin{tabular}{|c|c|c|c|c|c|}
\hline الكلي & المجال الفني & المجال الإداري & & فئات المتغير & المتغيرات \\
\hline 3.98 & 3.95 & 4.01 & المتوسط & \multirow{2}{*}{ ذكور } & \multirow{4}{*}{ الجنس } \\
\hline 0.844 & 0.975 & 0.753 & الانحراف & & \\
\hline 3.37 & 3.28 & 3.45 & المتوسط & \multirow{2}{*}{ إناث } & \\
\hline 0.985 & 1.147 & 0.94 & الانحراف & & \\
\hline 3.26 & 2.87 & 3.65 & المتوسط & \multirow{2}{*}{ أقل من • سنوات } & \multirow{6}{*}{ الخبرة التدريسية } \\
\hline 1.024 & 1.298 & 0.787 & الانحراف & & \\
\hline 3.72 & 3.70 & 3.74 & المتوسط & \multirow{2}{*}{ • 1 سنوات إلى أقل من } & \\
\hline 0.741 & 0.866 & 0.707 & الانحراف & & \\
\hline 3.79 & 3.79 & 3.80 & المتوسط & \multirow{2}{*}{ • ا سنواتٍ فأكثر } & \\
\hline 1.139 & 1.227 & 1.094 & الانحراف & & \\
\hline 3.93 & 3.88 & 3.99 & المتوسط & \multirow{2}{*}{ إنساني } & \multirow{4}{*}{ القسم } \\
\hline 0.909 & 1.032 & 0.818 & الانحراف & & \\
\hline 3.08 & 3.01 & 3.15 & المتوسط & \multirow{2}{*}{ علمي } & \\
\hline 0.811 & 1.056 & 0.777 & الانحراف & & \\
\hline 3.57 & 3.64 & 3.49 & المتوسط & \multirow{2}{*}{ محاضر } & \multirow{8}{*}{ الرتبة الأكاديمية } \\
\hline 0.881 & 0.883 & 0.976 & الانحراف & & \\
\hline 3.63 & 3.53 & 3.73 & المتوسط & \multirow{2}{*}{ أستاذ مساعد } & \\
\hline 1.034 & 1.234 & 0.883 & الانحراف & & \\
\hline 3.96 & 3.74 & 4.18 & المتوسط & \multirow{2}{*}{ أستاذ مشارك } & \\
\hline 0.768 & 0.887 & 0.676 & الانحراف & & \\
\hline 4.44 & 4.61 & 4.26 & المتوسط & \multirow{2}{*}{ أستاذ دكتور } & \\
\hline 0.231 & 0.324 & 0.147 & الانحراف & & \\
\hline
\end{tabular}

يتضح من الجدول (0) أن هناك فروقًا في الإحصائية بين المتوسطات الحسابية تم استخدام

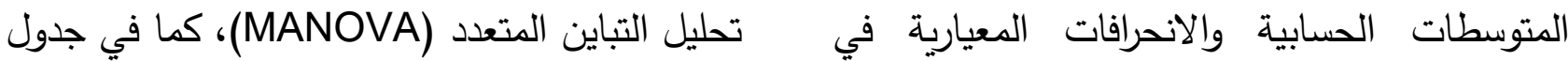
استجابات عينة الدراسة، ولبيان دلالة الفروق (†). 
جدول (؟): تحليل التباين المتعدد (MANOVA) للفروق بين المتوسطات الحسابية لتقديرات أفراد العينة للرقابة الإدارية حسب متغيرات الاراسة.

\begin{tabular}{|c|c|c|c|c|c|c|}
\hline الدستوى & قيمة ف & متوسط المربعات & الحرية & مجموع & الرقابة الإدارية & المتغيرات \\
\hline 0.003 & 9.194 & 5.49 & 1 & 5.49 & المجال الإداري & \multirow{3}{*}{ الجنس } \\
\hline 0.005 & 8.277 & 8.073 & 1 & 8.073 & المجال الفني & \\
\hline 0.003 & 9.228 & 6.719 & 1 & 6.719 & الكلي & \\
\hline 0.092 & 2.422 & 1.446 & 2 & 2.892 & المجال الإداري & \multirow{3}{*}{ الخبرة التدريسية } \\
\hline 0.019 & 4.07 & 3.97 & 2 & 7.94 & المجال الفني & \\
\hline 0.180 & 1.733 & 1.262 & 2 & 2.524 & الكلي & \\
\hline 0.000 & 30.327 & 18.108 & 1 & 18.108 & المجال الإداري & \multirow{3}{*}{ 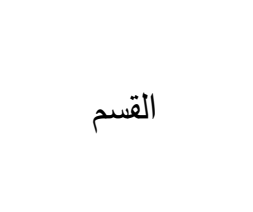 } \\
\hline 0.000 & 15.968 & 15.574 & 1 & 15.574 & المجال الفني & \\
\hline 0.000 & 23.095 & 16.817 & 1 & 16.817 & الكلي & \\
\hline 0.058 & 2.683 & 1.602 & 3 & 4.805 & المجال الإداري & \multirow{3}{*}{ الرتبة الأكاديمية } \\
\hline 0.123 & 1.95 & 1.902 & 3 & 5.707 & المجال الفني & \\
\hline \multirow[t]{7}{*}{0.289} & 1.262 & 0.919 & 3 & 2.757 & الكلي & \\
\hline & & 0.597 & 172 & 102.7 & المجال الإداري & \multirow{3}{*}{ الخطأ } \\
\hline & & 0.975 & 172 & 167.76 & المجال الفني & \\
\hline & & 0.728 & 172 & 125.25 & الكلي & \\
\hline & & & 180 & 2678.4 & المجال الإداري & \multirow{3}{*}{ المجموع } \\
\hline & & & 180 & 2604.4 & المجال الفني & \\
\hline & & & 180 & 2625.6 & الكلي & \\
\hline
\end{tabular}

يتضح من نتائج جدول (7) وجود فروق دالة لصالح الأكور، ويفسر الباحث هذه النتيجة بأن

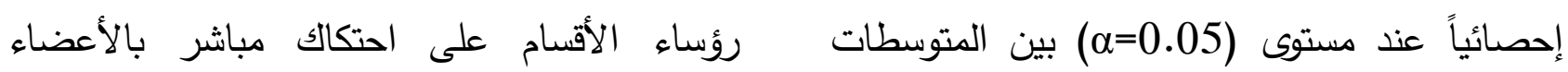
الحسابية في درجة ممارسة رؤساء الأقسام في الذكور، ذلك أن رؤساء الأقسام يتواجدون في قم جامعة نجران للرقابة الإدارية لجميع المجالات وعلى البنين، فهم أكثر متابعة لأعضاء هيئة التدريس من الدرجة الكلية تعزى لاختلاف متغيرات الدراسة الذكور من خلال التعرف على مشكلاتهم ومساعدتهم (الجنس، القسم)؛ ففي متغير الجنس جاءت الفروق في حلها. وقد اتفتت هذه النتيجة مع دراسة الزعبي 


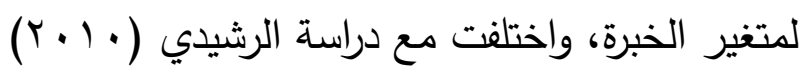
التي أشارت إلى عدم وجود فروق دالة إحصائياً في درجة ممارسة الرقابة الإدارية تعزى لمتغير الخبرة. وفي متغير الرتبة الأكاديمية: أشارت نتائج تحليل التباين إلى عدم وجود فروق دالة إحصائياً لدرجة الحتبه

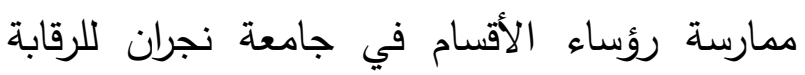

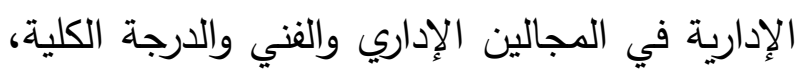
ويعزو الباحث هذه النتيجة إلى أن رؤساء الأقسام

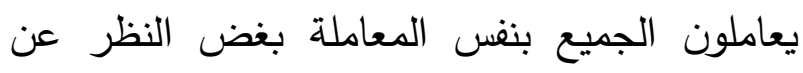

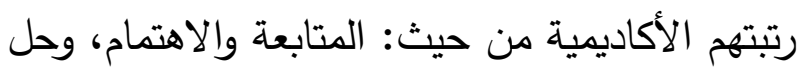

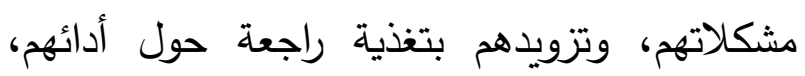

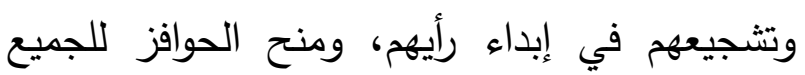
دون استثناء، ويعود ذلك لدرجة الوعي التي يتمتع بها رؤساء الأقسام في أهمية الرقابة في المحافظة

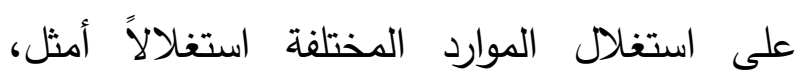

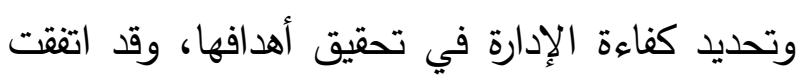

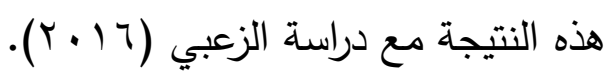
توصيات الدراسة:

في ضوء نتائج الدراسة يوصي الباحث بما يأتي:

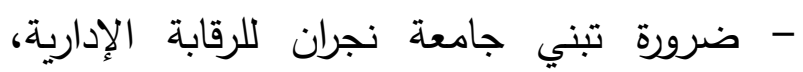

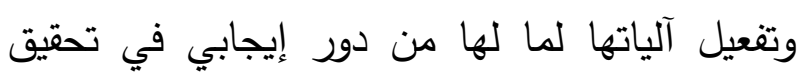
أهداف الجامعة ورؤيتها، وتطوير أداء العاملين فيها. - ضرورة وضع آليات لمتابعة مشكلات أعضاء هيئة التدريس المختلفة (رواتب، إجازات، ترقيات)

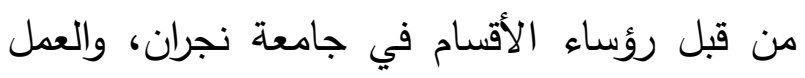
على حلها.

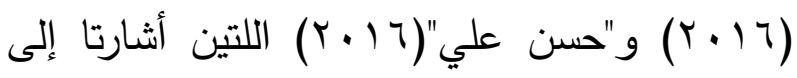
وجود فروق دالة إحصائياً في درجة ممارسة الرقابة الإدارية تعزى لمتغير الجنس.

وفي متغير القسم: يعزو الباحث النتيجة في وجود فروق في ممارسة رؤساء الأقسام في جامعة نجران للرقابة الإدارية في المجالين الإداري والفني والدرجة الكلية لصالح الأقسام الإنسانية إلى أن هذه الأقسام

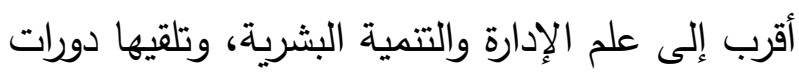
تدريبية في مجال التنمية البشرية والتطوير الإداري

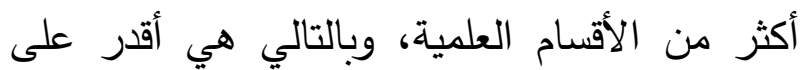
القيام بمهام الرقابة الإدارية. وفي متغير الخبرة التدريسية: أثارت نتائج تحليل التباين إلى عدم وجود فروق دالة إحصائياً في درجة ممارسة رؤساء الأقسام في جامعة نجران للرقابة الإدارية في المجالين الإداري والفني والدرجة الكلية، ويعزو الباحث هذه النتيجة إلى أن أعضاء هيئة الإداءئ ولثيه التدريس من مختلف الخبرات القليلة والمتوسطة والطويلة يلاقون الدرجة نفسها من الرقابة والمتابعة من قبل رؤساء الأقسام، ولديهخ تصورات مشتركة

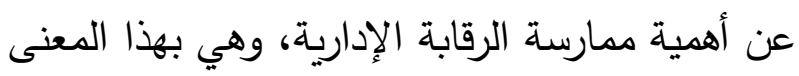

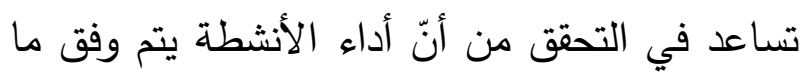

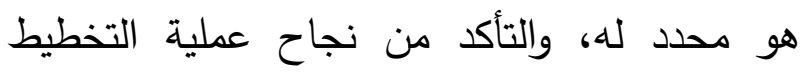

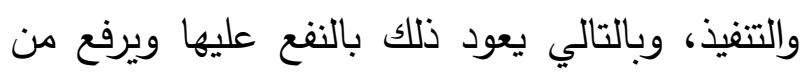
مستواها. وقد اتفقت هذه النتيجة مع دراسة ياسين بعان

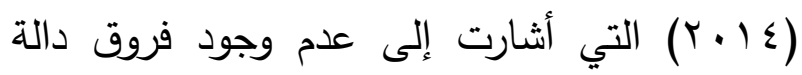
إحصائياً في درجة ممارسة الرقابة الإدارية تعزى إنى 
مجلة الأندلس للعلوم الاجتماعية وإلتطبيقة، . $1 .-1 \cdot 6(1 \cdot)^{0}$ البلوشي، طلال بن عبدالله (9 . . r م). نموذج مقترح لرقابة الأداء على المشاريع التربوية التطويرية في

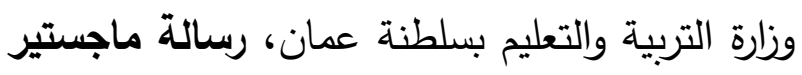
غير منثورة، جامعة السلطان قابوس، سلطنة عمان.

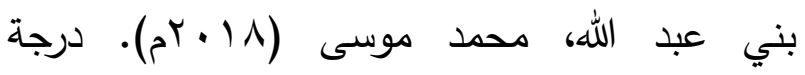
ممارسة مديري المدارس الثانوية الحكومية للرقابة

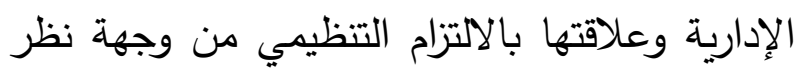

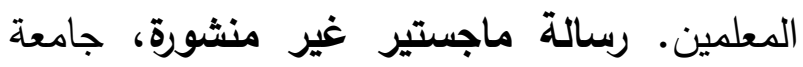
عمان العربية، عمان، الأردن.

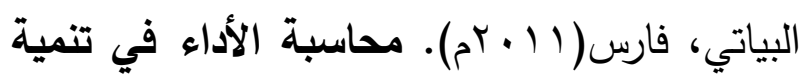

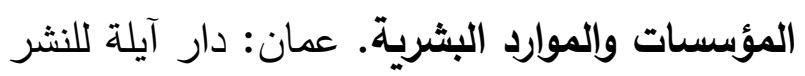
والتوزيع. "حسن علي"، مرح طاهر (7 ( • rم). الرقابة الإدارية

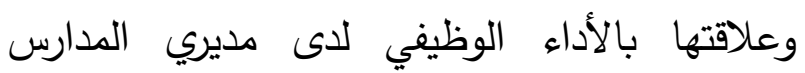

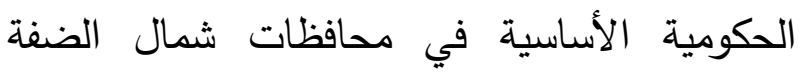
الغربية من وجهات نظر المديرين أنفسهم. رسالة

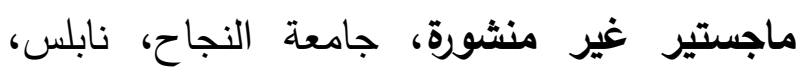
فلسطين.

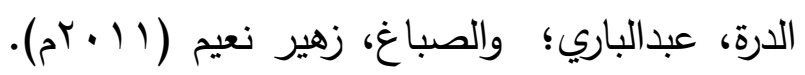

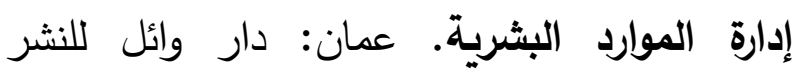
والتوزيع.

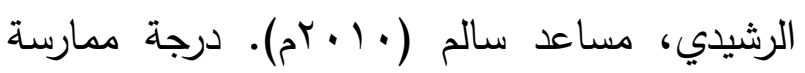
الرقابة الإدارية في المدارس الحكومية الثانوية في
- ضرورة وضع آليات لإعداد ميزانية سنوية للقسم وفق الإمكانات المتاحة، لتلبية احتياجات القسم المختلفة، مع ضرورة توفيرها من قبل الجامعة. - ضرورة قيام جامعة نجران بعمل دورات تدريبية

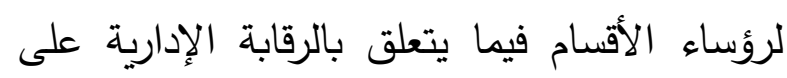
المجالات كافة. - ضرورة قيام رؤساء الأقسام بتشجيع الرقابة الذاتية عند أعضاء التدريس والطلبة.

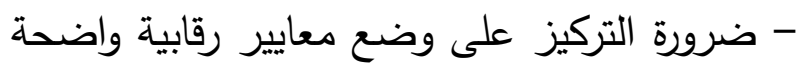

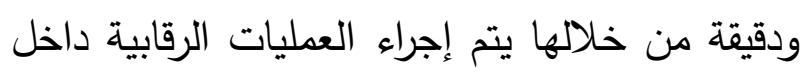
الأقسام العلمية بجامعة نجران. مقترحات الاراسة:

تقترح هذه الدراسة إجراء بعض الدراسات في المجال ذاته، ومن ذلك: - إجراء دراسات مماثلة لهذه الدراسة على القيادات الأكاديمية بالجامعات، وإدخال متغيرات أخرى مثل:

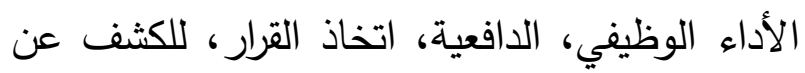
علاقتها بالرقابة الإدارية. - وضع تصور مقترح لتفعيل أساليب الرقابة الإدارية في الجامعات السعودية. المصادر والمراجع المراجع العربية برقعان، أحمد محمد؛ وسعيد، عبدالحكيم رضوان؛

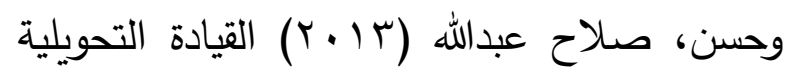
لاى رؤساء الأقسام في بعض اعل الجامعات السعودية، 


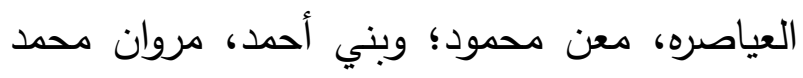

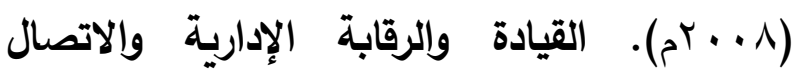
الإداري، عمان: دار الحامد للنشر والتوزيع.

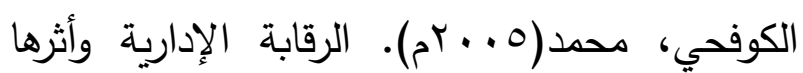

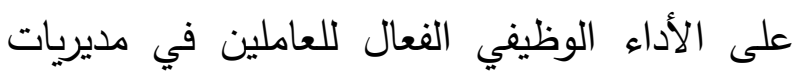

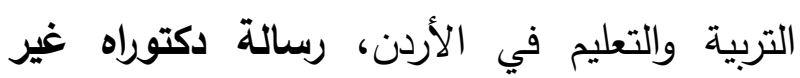
منثورة، جامعة اليرموك، إربد، الأردن.

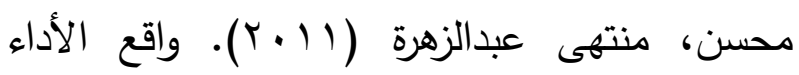
الإداري لدى رؤساء الأقسام في كليات التربية بجامعة بغداد من وجهة نظر أعضاء هيئة التدريس،

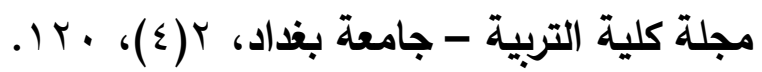

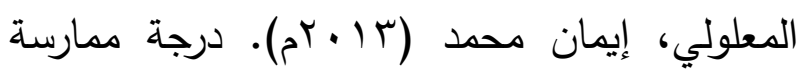
مديري المدارس للرقابة الإدارية وعلاقتها بالأداء الوظيفي للمعلمين من وجهة نظر المعلمين والمديرين. رسالة ماجستير غير منشورة، جامعة مؤتة، الكرك، الأردن. المعلولي، إيمان؛ والقضاة، محمد أمين (2016م) مونه درجة ممارسة مديري المدارس للرقابة الإدارية وعلاقتها بالأداء الوظيفي للمعلمين من وجهة نظر مايري

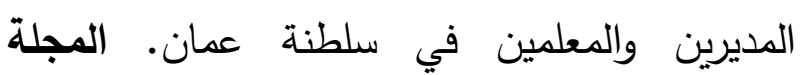

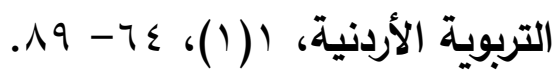
مهودر، هيفاء نجيب (Y ( • (ז)). الرقابة الإدارية.

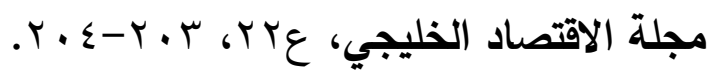

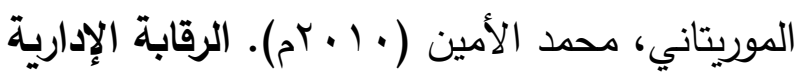
في العها الراشدي، بيروت: دار الكتب العلمية.
منطقة حائل من وجهة نظر المعلمين. رسالة ماجستير غير منشورة، جامعة مؤتة، الكرك، منه لطرين،

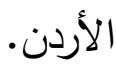

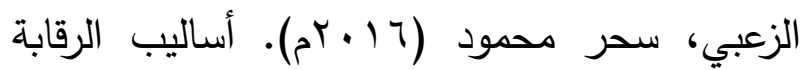
الإدارية لدى مديري المدارس الثانوية في محافظة الزرقاء وعلاقتها بمستوى الأداء الوظيفي للمعلمين. رسالة ماجستير غير منشورة، الجامعة الهاشمية،

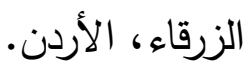
الشواشرة، فيصل (0. . بام). مبادئ إدارة الأعمال. عمان: دار وائل للنشر والتوزيع.

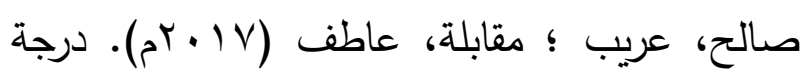
تطبيق مديري المدارس الثانوية الحكومية والخاصة للرقابة الإدارية من وجهة نظر المعلمين. دراسات - لإئ

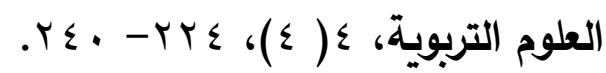

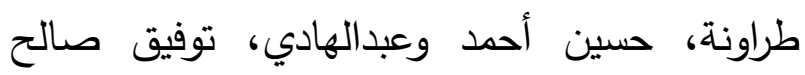

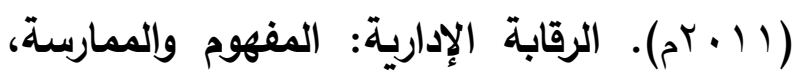
عمان: دار الحامد للنشر والتوزيع. الظاهر، نعيم (9 . . بم). أساسيات الإدارة المبادئ والتطبيقات الحديثة، عمان: جدارا للكتاب العالمي للنشر والتوزيع.

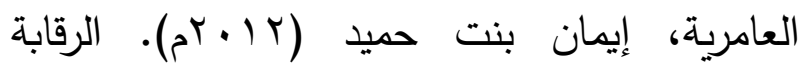
الإدارية على مؤسسات التعليم العام في سلطنة عمان (تصور مقترح)، رسالة ماجستير غير فئرئ منشورة، جامعة السلطان قابوس، سلطنة عمان. 


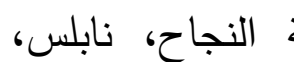

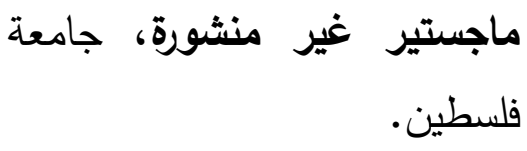

\section{المراجع الأجنبية}

boyd, D \& et al. (2009). The influence of school administrators on teacher retention decisions, New York city Department of education and the new York state Education Department, journal of higher education, 114, pp497 - 532.

Carruthersy, C. (2008). The Qualifications and Class room Performance of Teachers Moving to Charter Schools, Unpublished Doctoral, of American university.

Eric, A (2008). Teachers, schools, and academic achievement, econometric, 73(2),pp417-458.
ياسين، إسراء ياسين (ع ا •rم). درجة فاعلية الرقابة الإدارية ودرجة تطبيق الأداء الوظيفي لاى مديري المدارس الحكومية الأساسية ومديراتها في محافظات الضفة الغربية من وجهة نظر المعلمين. رسالة Grigorescu, V. (2003). Transparency and the impact of international organization on democratic consultation, Unpublished Doctoral, of Valencia university..

Mizala, A. (2004). School and teacher performance incentives: the latin american experience, Economics of Education Review 11 (1), pp 71-86.

Zhang, S, (2008). The necessities, feasibilities, and principles for teacher to build a learner oriented monocarps for practical classroom uses, professional teaching articles, journal of educational psychology. 


\title{
The Degree of practice Control Application by the heads of departments at the University of Najran from faculty members Perspectives
}

\author{
Hadi Salem Al-ajmi \\ Assistant professor of Educational Administration, \\ Faculty of Sciences and Arts in Sharurah, Najran University
}

\begin{abstract}
Control Application by the heads of departments at Najran University from faculty members Perspectives. and to determine the difference in the degree of practice administrative control according to the impact of study variables, the researcher used descriptive analytical method. A questionnaire was designed to collect the data. The study sample included 180 members, (97) males and (83) females were selected by random method, Results revealed that the degree of practice Control Application by the heads of departments at Najran University was high At the level of the total tool and on the administrative and technical fields. There were statistically significant differences in the degree of practice Control Application by the heads of departments at Najran University due to (sex, department), There were no statistically significant differences in the degree of practice Control Application by the heads of departments at Najran University from faculty members due to (teaching experience, academic rank). The study recommended the need of adopting Najran University for Administrative Control and activating its mechanisms because of its positive role in achieving the objectives of the university and its vision, and developing the performance of its employees.
\end{abstract}

Keywords: Administrative Control, Administrative Processes, Department Heads. 